University of Louisville

ThinkIR: The University of Louisville's Institutional Repository

Electronic Theses and Dissertations

1941

\title{
The effect of varying surface tension on the rate of carbon dioxide absorption in water.
}

Sheldon Hutchison Butt 1919-1994

University of Louisville

Follow this and additional works at: https://ir.library.louisville.edu/etd

Part of the Chemical Engineering Commons

\section{Recommended Citation}

Butt, Sheldon Hutchison 1919-1994, "The effect of varying surface tension on the rate of carbon dioxide absorption in water." (1941). Electronic Theses and Dissertations. Paper 1676.

https://doi.org/10.18297/etd/1676

This Master's Thesis is brought to you for free and open access by ThinkIR: The University of Louisville's Institutional Repository. It has been accepted for inclusion in Electronic Theses and Dissertations by an authorized administrator of ThinkIR: The University of Louisville's Institutional Repository. This title appears here courtesy of the author, who has retained all other copyrights. For more information, please contact thinkir@louisville.edu. 


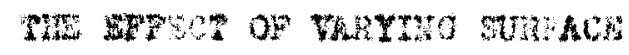

MESTON OW TEE RAT OF

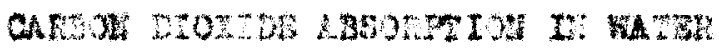

Shelcon Sutoh1 an Autt

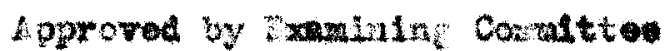
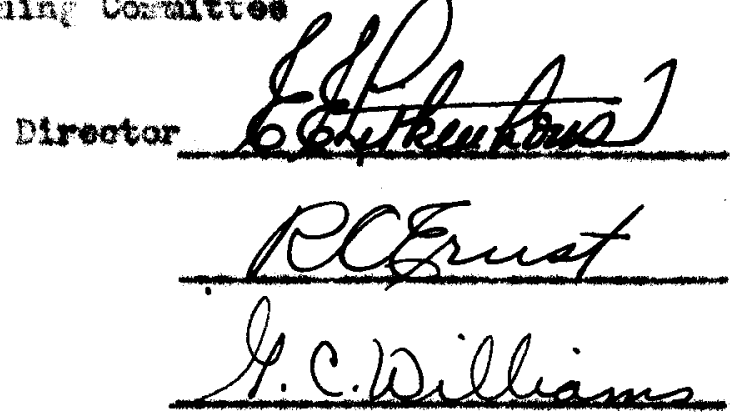

O. R. Wiecions

Bt. Ointer

May 20,124

$-9$

$1 \frac{0}{2}$

j

13461 


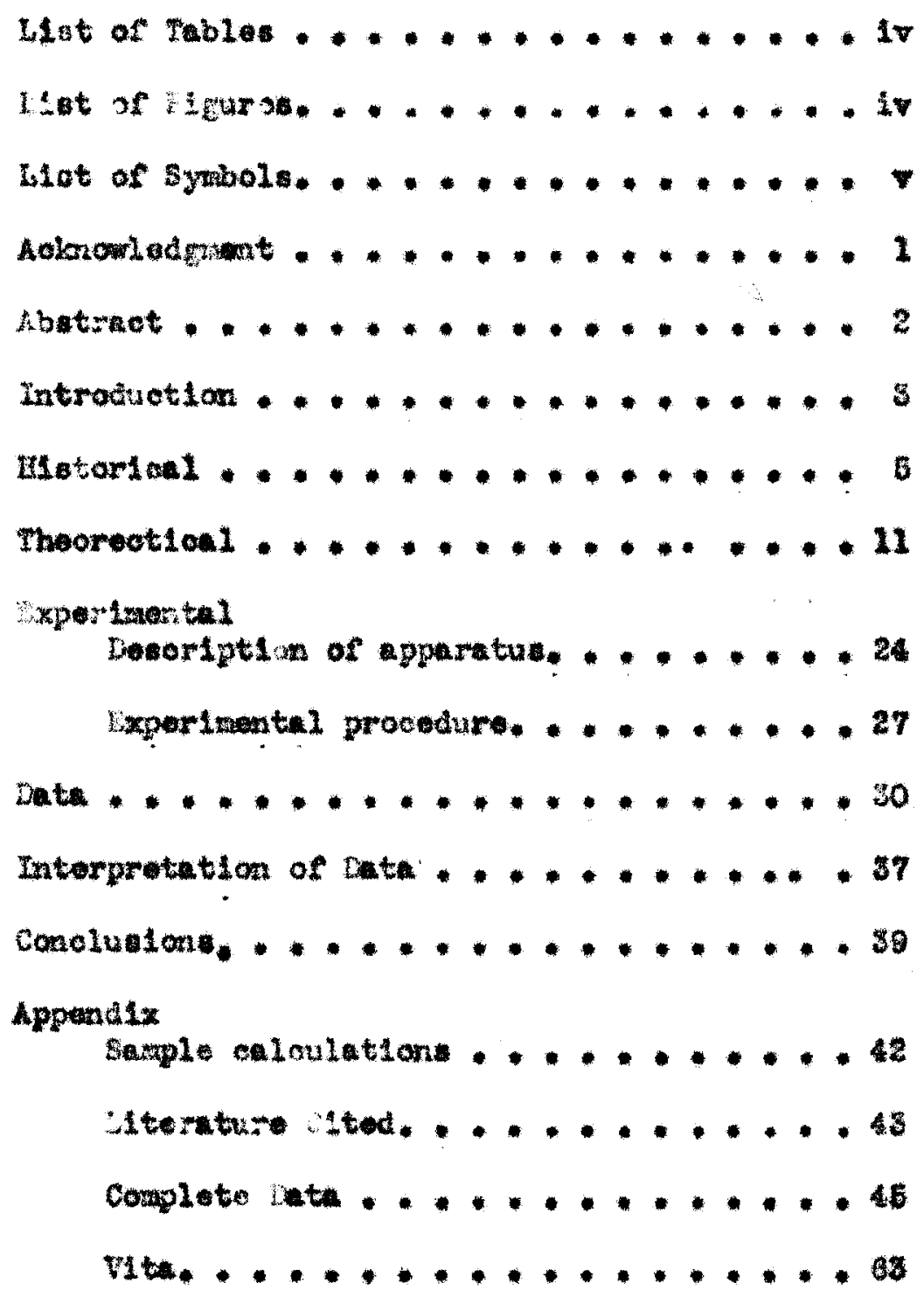




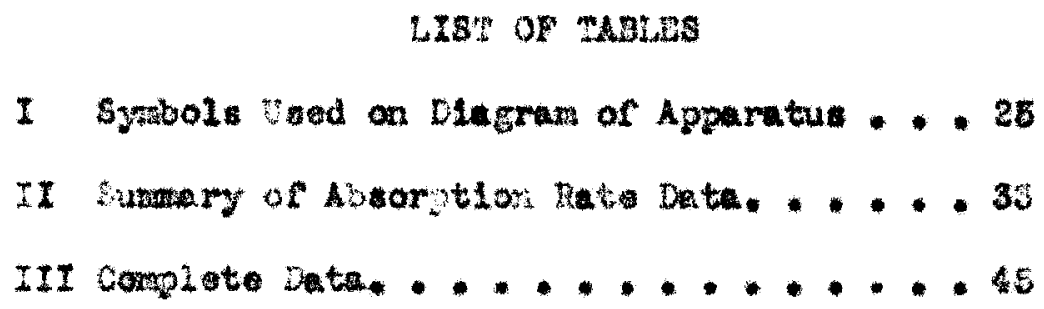

LIST or ETmes

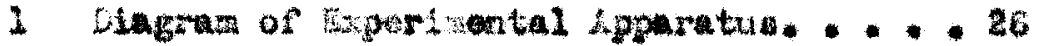

2 Aborgtion tiate va. Surfuee Tonalon

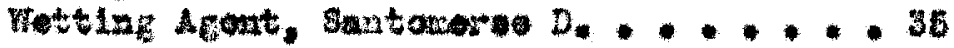

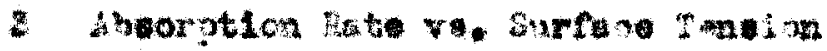

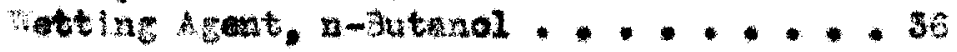


A

ts Thioloness of $\mathrm{film}$

$c$

-

$D_{2}$

I

I

x

x

n

n

?

R

a

T

u

$\mathbf{v}$

sub A component A

tub $A B$ A through $B$

aub aA B through A

wub $B$ compent $B$

oub \& Gas

wub 1 Interface

aub 1 Liquid 


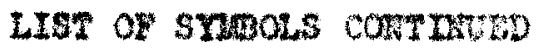

\author{
$\beta$ conertolent of renteturio \\ $\mu$ visoostty of 11quid \\ $\theta$ rin \\ W Artial wolal rolute
}




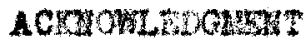

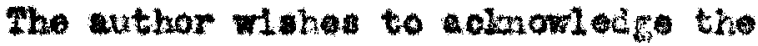
ind astotance and holoni hulance

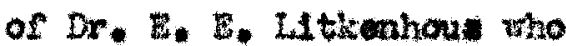
directed thi researoh 


\begin{abstract}
A.3 SRACT

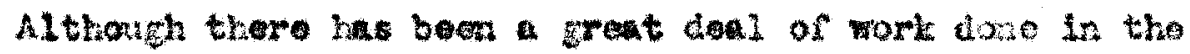

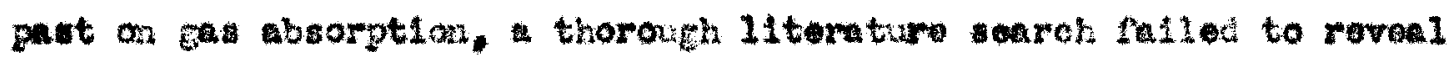

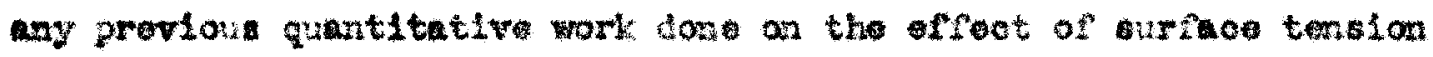
on aborption rated. A batch absorgtion eysten ulat the oarbon daxide

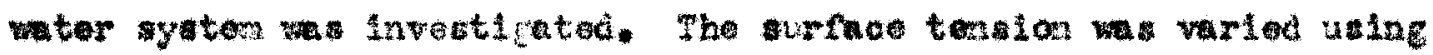

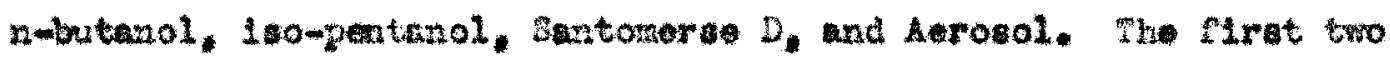
were how to prodece a marted inorense in absorption rate wh cocrease

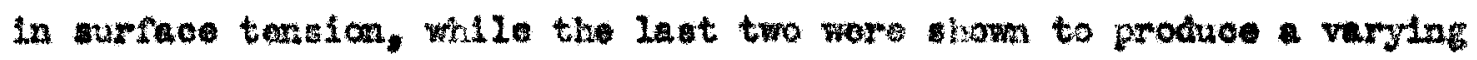

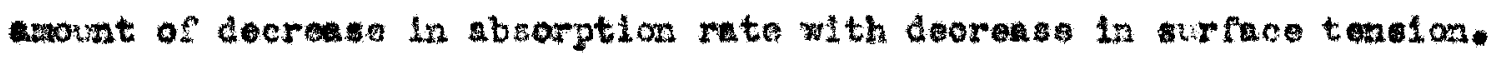

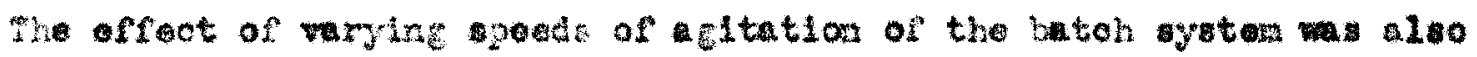
invertigatel. No theoratloal corralation has realtec from the experi-

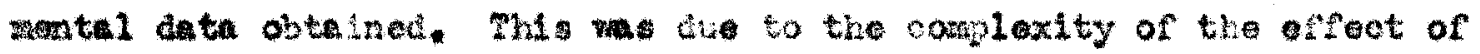

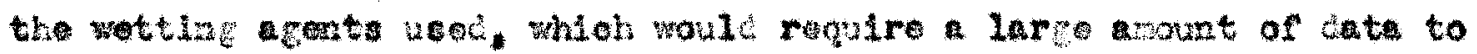
obtain correlation.
\end{abstract}


In's 


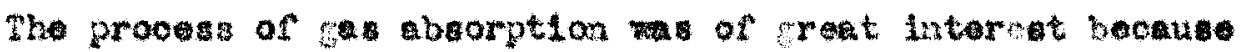

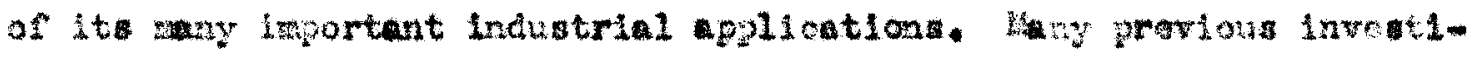

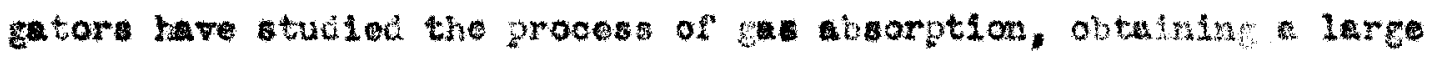

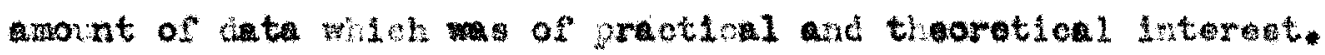

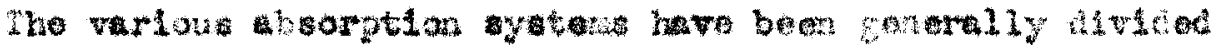

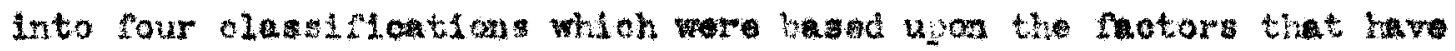

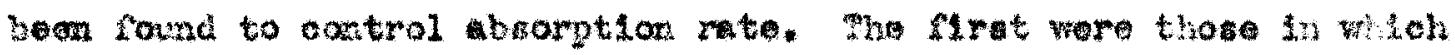

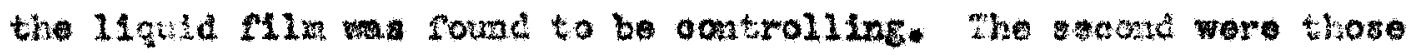

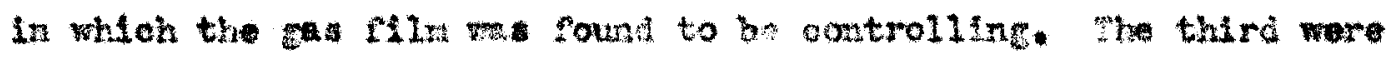
those in whin both fllme were found to bo controlling. wh1 the fourth were thos in whoh the cborbed renoto the solvent

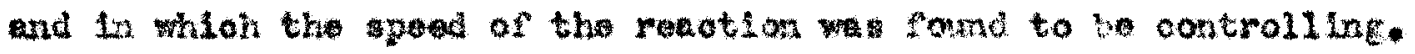

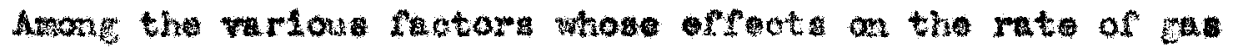

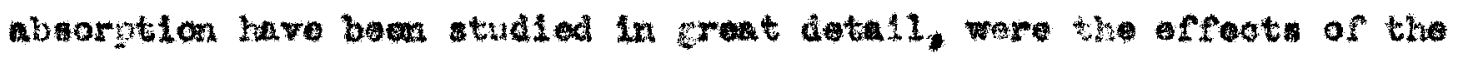

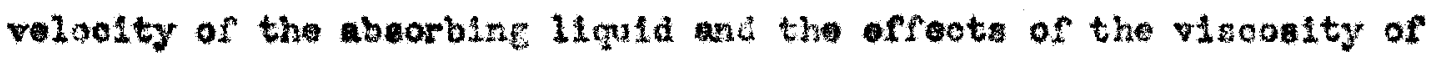
the aborblne 11 atd.

The furpos of thi Investigation to deternalue the effect

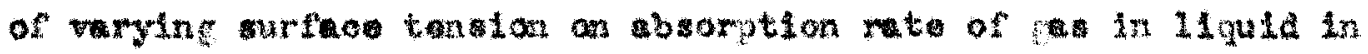

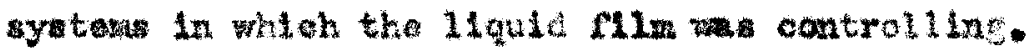

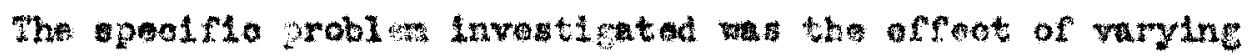

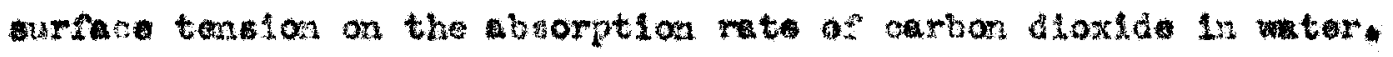


IISTORICA 
The derolopment of theory of aborption mato wa of

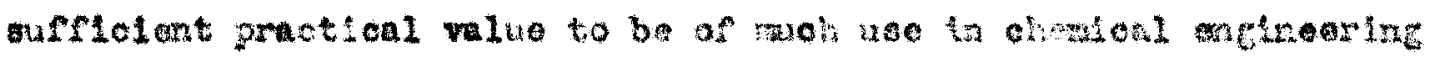

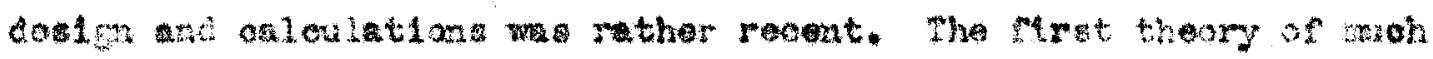

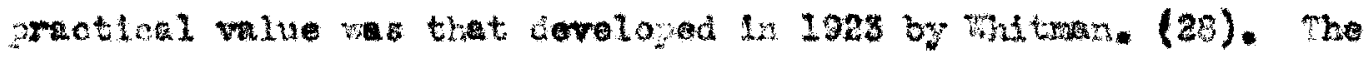

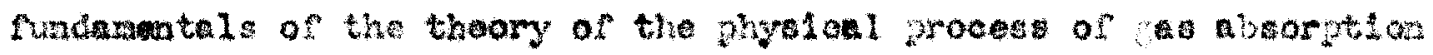

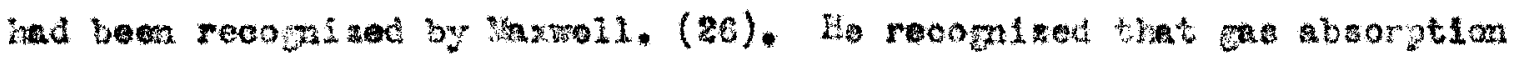

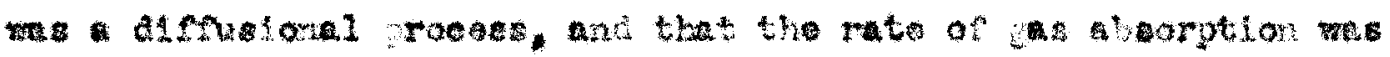

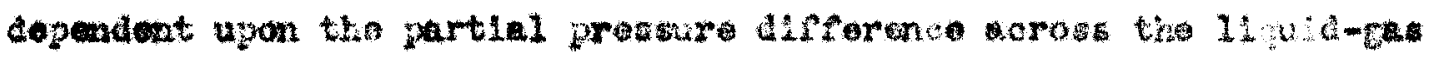

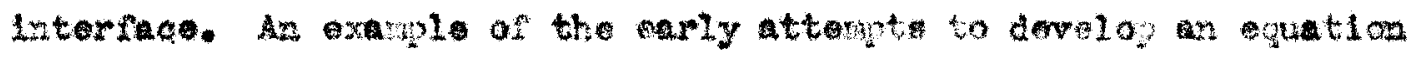

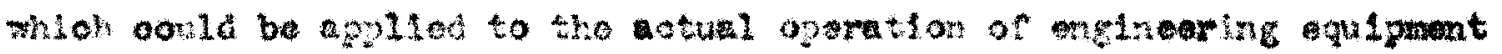
was the work cone by pater. (4).

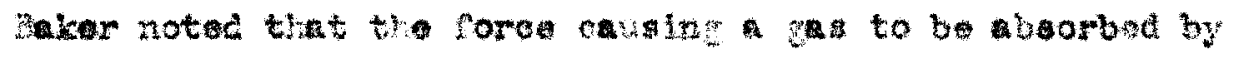

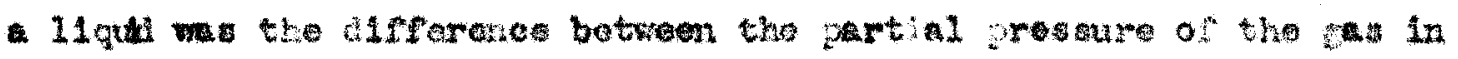

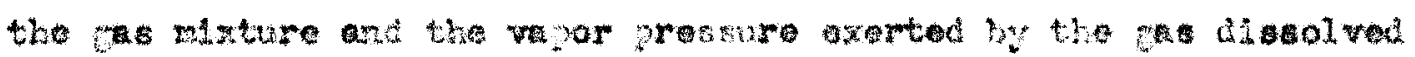

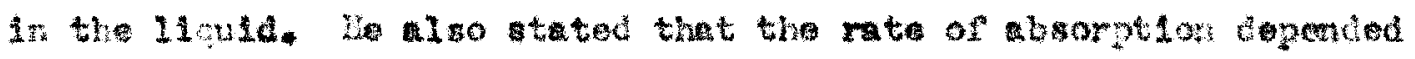

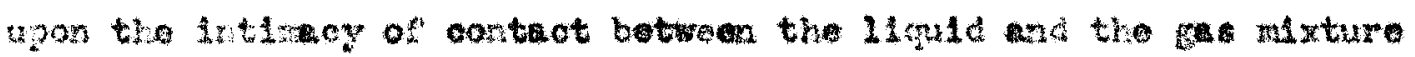

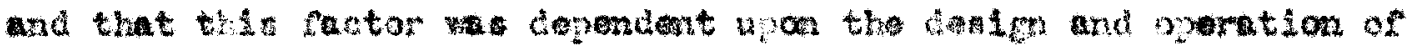

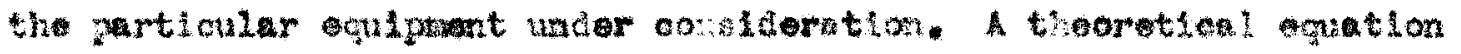

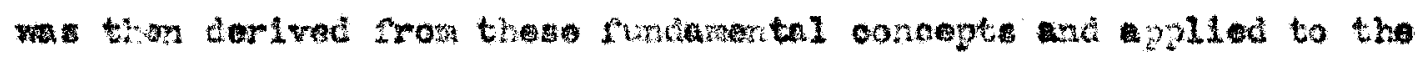
avallable deta. Ie proposed the follanine equation:

$$
\begin{aligned}
& \frac{d u_{M}}{a_{L}}=\left(\mathrm{P}_{\mathrm{AC}}-\mathrm{p}_{\mathrm{A}}^{*}\right) \\
& \text { ân Aborptica rate }
\end{aligned}
$$

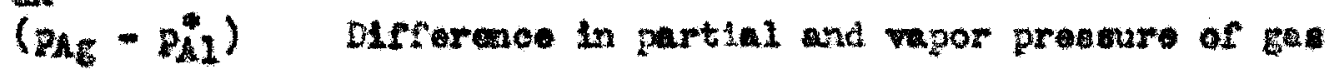

$$
\begin{aligned}
& \text { c Proportlonal Ity oonutast } \\
& \text { I Feotor representing the intimay of contaot of gac } \\
& \text { and liquid phases }
\end{aligned}
$$




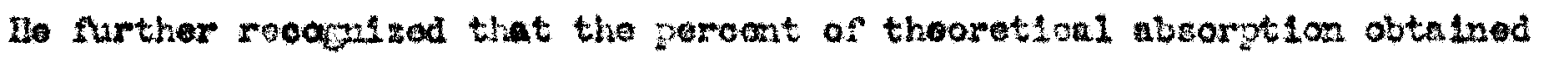

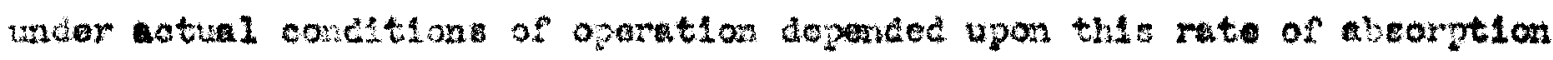

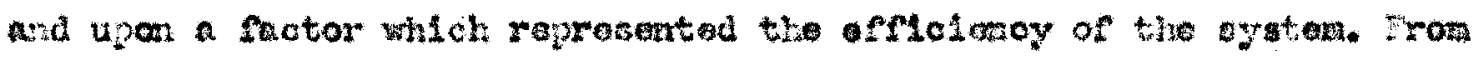
the on odyts ho coveloped the equation:

$$
\begin{aligned}
& \frac{a_{A}}{a_{A}}=c_{2} c+\left(p_{A E}-2 A_{1}\right) I \theta \\
& c_{2} \text { Proportand:ty contant } \\
& \text { c. affetenoy factor } \\
& \theta \text { rine of comet }
\end{aligned}
$$

Tt wa aparent bat although this oquation wa theoretially sound. 1t ses of 11ttlo praction ralue. Gech purtlcular 3at of proooss

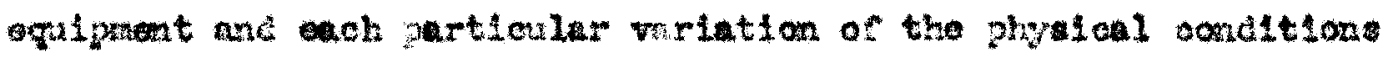

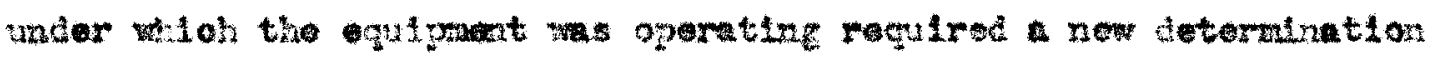

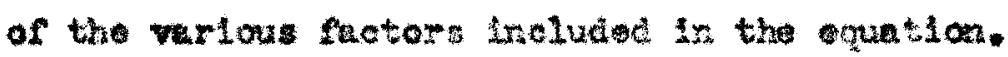

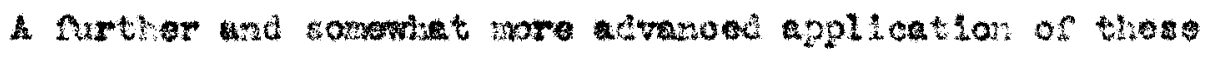

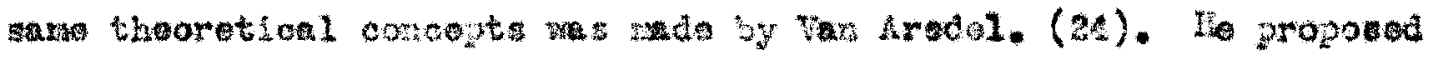
as Andanmat oguation the following

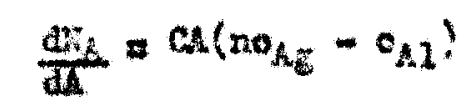
$\boldsymbol{A}$
Arew of contest

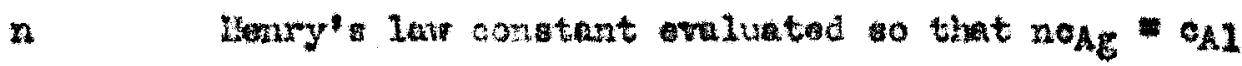
o Concentration ar A In fas phase

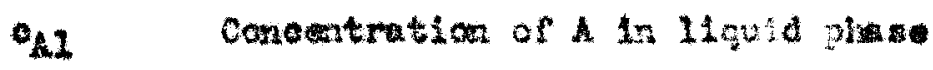
C Proportionility oonstant

Ven Aredel thes procseded to adapt thi oquation to poked tower obtuining the following oxpresston:

$$
x \quad \frac{d W_{A}}{d A}=\operatorname{Ar}\left(n o_{A E}-o_{A L}\right)_{a v} .
$$

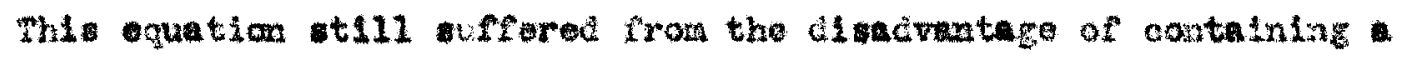




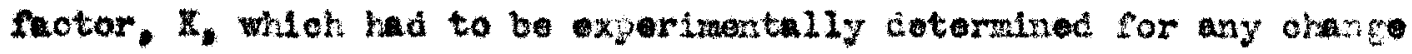

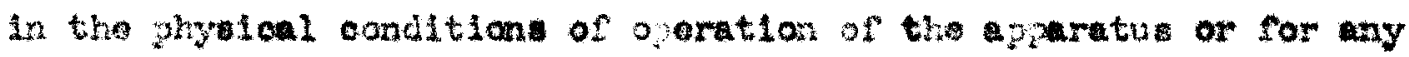
change in the oongonente of the aystera.

Van Araciel (25) also wad an attot at corroletion of dath

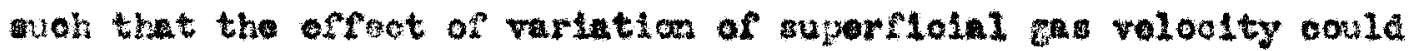
bo take luto cocount.

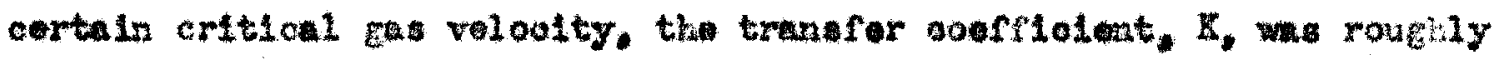

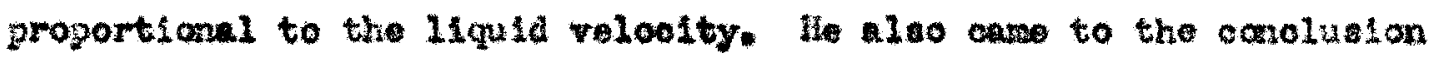
that this ane tranefer coefflolent warled inversely a the viscontty of the 11 quid intese.

Tho atot Inportant single acivanoe in tho study of the theory of gas absorption the postalation of the double llia conoept of

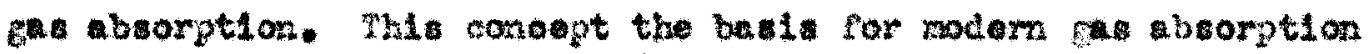

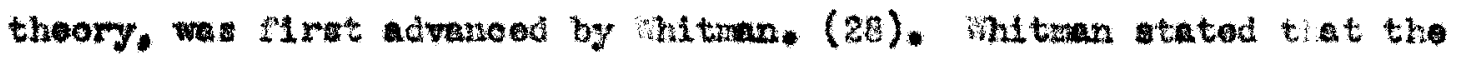
overall coofflelent of waterial trans orred cold be defined according to the following equations

$$
x_{A}=\frac{1}{x_{E}+T_{I}}
$$

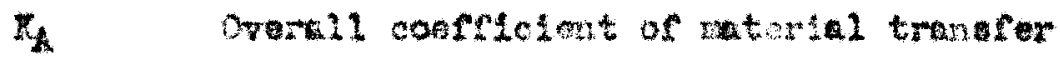

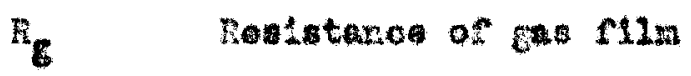

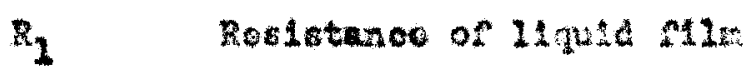

mis two flu concopt of gar abortion w11 be dealt with further 15 tho cetion of this thesio devoted to thory.

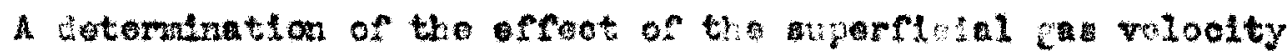

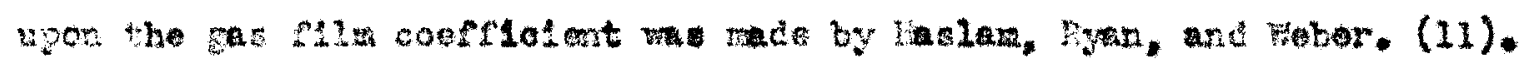

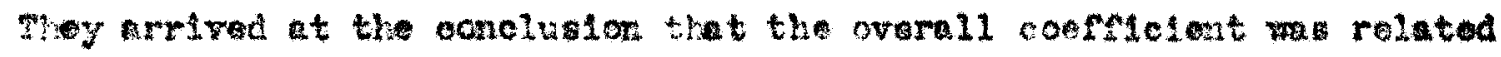


to ras velocty by the following axprestom:

$$
\frac{1}{n_{1}}=\frac{c}{1000}+R_{1}
$$

V Dat relocity

Turther rowk of the effect of the Hscolty of the dorbing

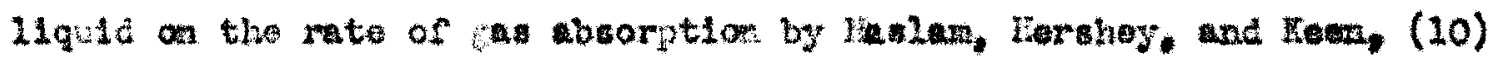

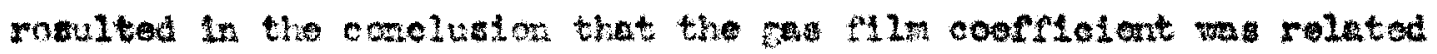
to wacity and peolty by the andion:

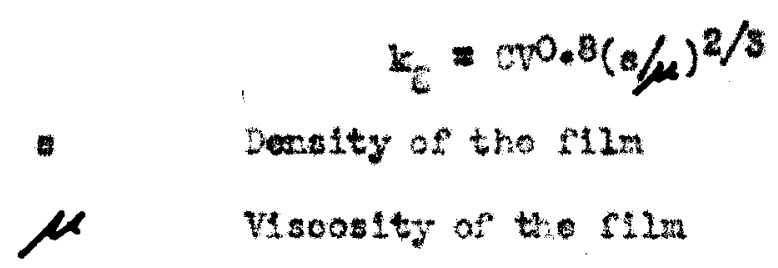

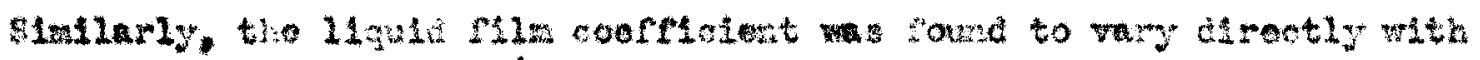

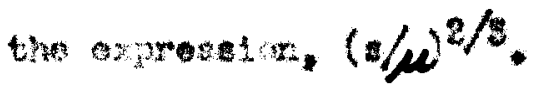

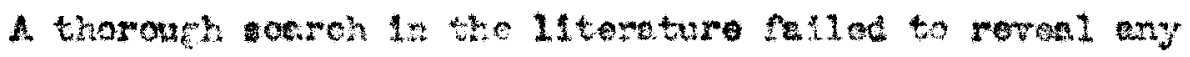

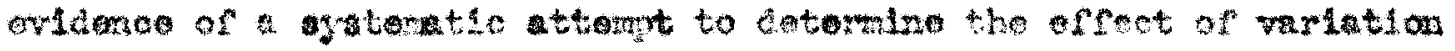

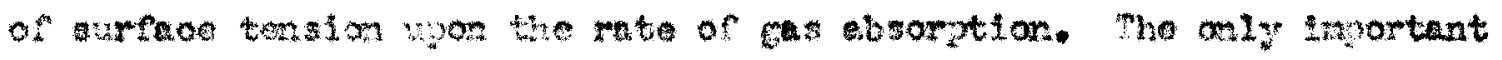
reforane (2z) to any investigation of the vo of rotting agonts in

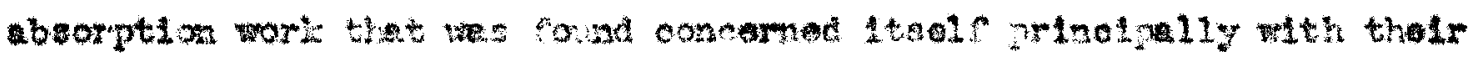

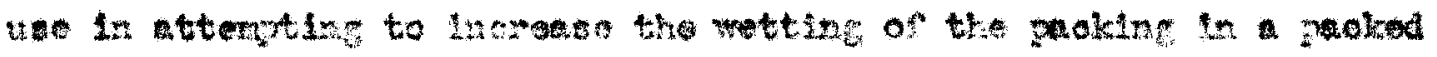
Lbsorgtion fower. The referano atsted only that the eddition of the

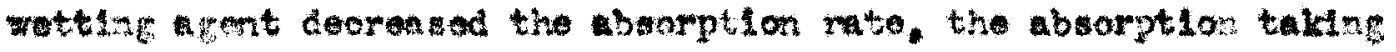

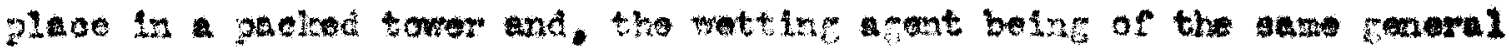

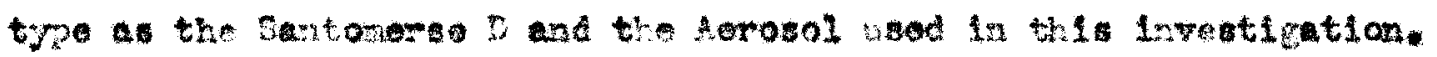

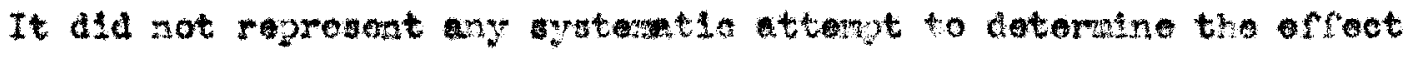

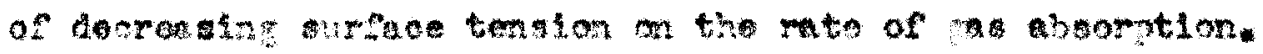

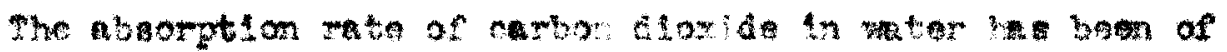




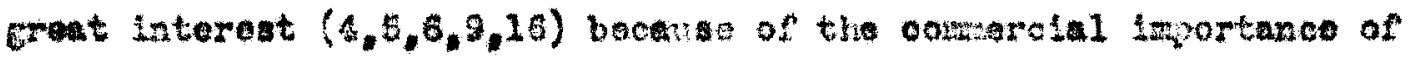

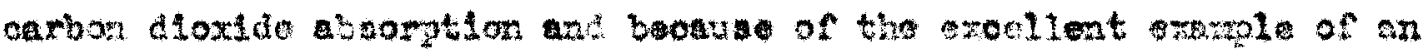

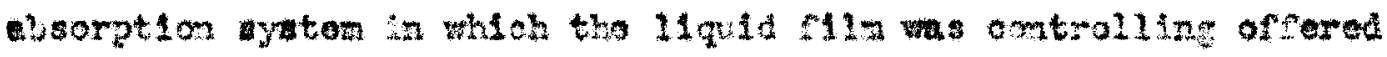

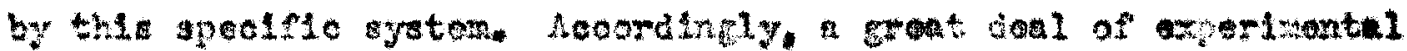
work ha bem come in the past on the cotornitatlax of the ravious

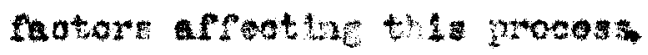


11

WORET TOR 
The proces of gas aborption was derined for the purposes

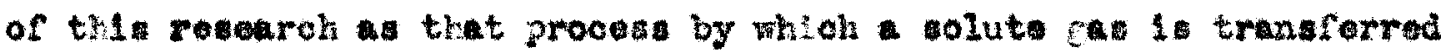

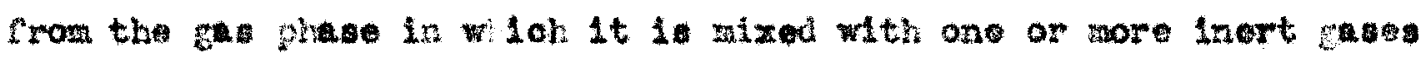

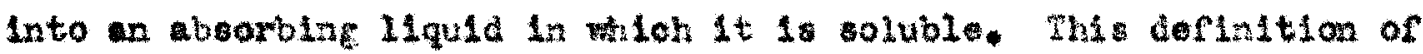
the process of gas losorption was quite ln areonent with the generally accepted one. The nost wdely coopted theory whloh ha boen coveloped

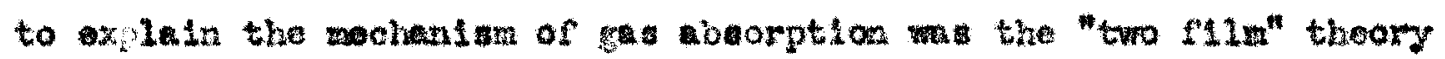

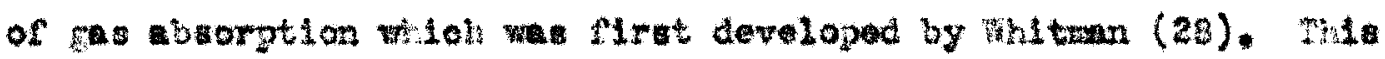

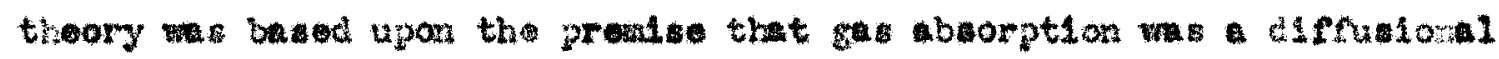

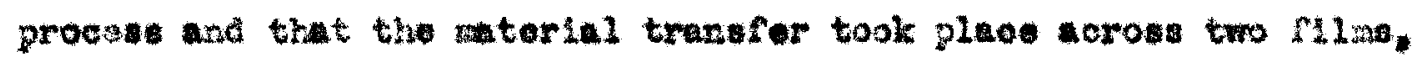

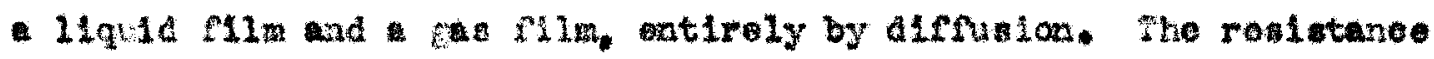

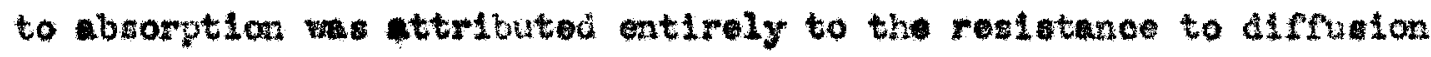

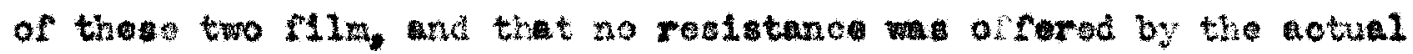
1iquid-gar linterinee.

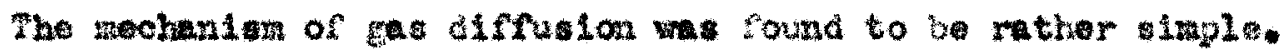

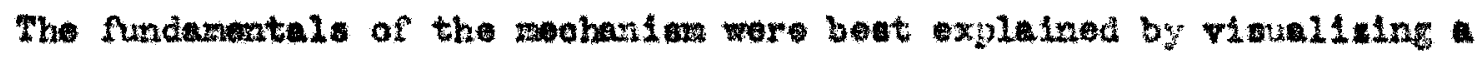

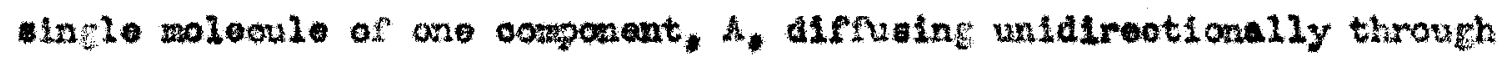

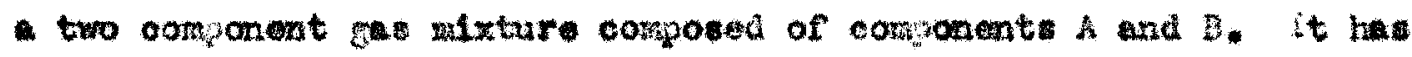

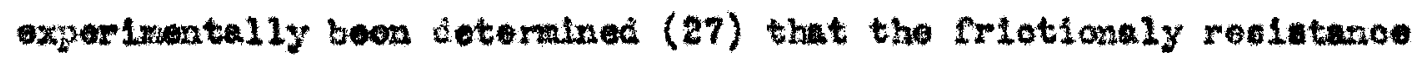

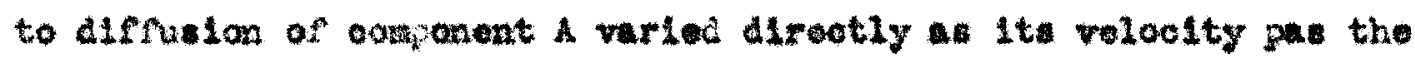
Interfering. It he also bech datermined that the rosistence to

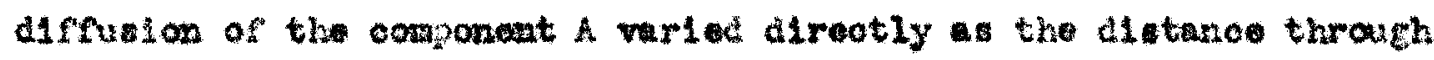

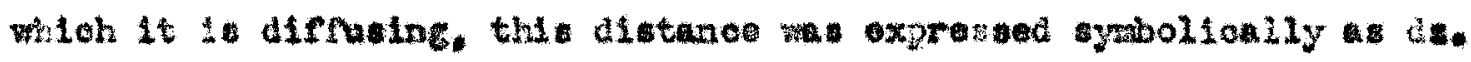

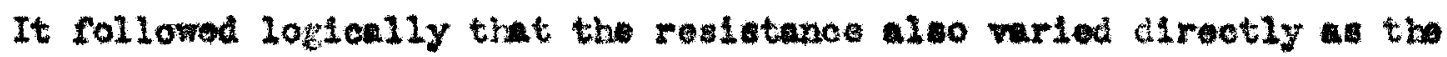

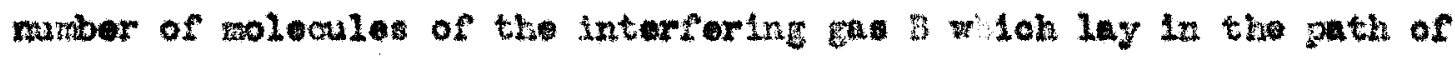
the molocule of $A$. The value wa proportionel so the partinl nolol 
volume of $3, D_{B}$. By ouration, the concluaton was rowohed that the totel resistance to diffuston of componont $A$ no ogual to the number

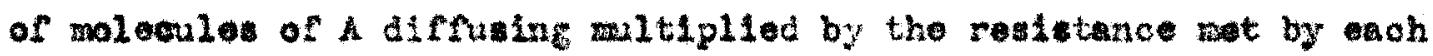
molecule. Since the number of nolooules of A wa la proportional

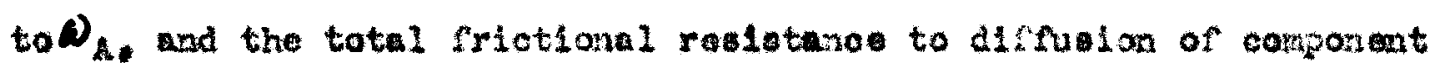
A wa equal to $\beta_{A B} \omega_{A} \omega_{B}\left(u_{A}-u_{A}\right)$. hero:

$$
\begin{array}{ll}
\beta_{A} & \text { coefficient of resistinos } \\
u_{A} & \text { veloeity of component } A \\
u_{B} & \text { Voloolty of component } B
\end{array}
$$

To cause any Mow of the component $A$ a force that would orercon the resiatunoe to difitus on of A had to axlat. Fhis force was applied by an oquivelent drop in tho partial prossurs of $A$.

$$
-a_{A}=\beta_{A B} \omega_{A} \omega_{B}\left(u_{A}-u_{B}\right) d s \text {, or } \frac{d p_{A}=}{d A} \beta_{A} \omega_{A} \omega_{B}\left(u_{A}-u_{B}\right)
$$

sinllarly, we wey we the expreselon:

$$
\frac{c_{n}}{d A}=\beta_{A B} \omega_{A} \omega_{B}\left(u_{A}-u_{B}\right) \quad(E 2)
$$

It was well lnow that if there we no signiflcant motion of the whole body of the was, the tothl prosaro, $P$, of the was wald ram in constant throughout the aystem. Since the total prosmare oqualed the sum of the partial presures, that it,

$$
p=p_{A}+p g
$$

Differeatiution of this equation yieldad the exprosion.

$$
d p_{A}+d p_{Y}=0
$$

That 1s, the partial preasures of $A$ and $B$ when diffezentlated wore oqual but opposite in 1ga. ay equating oquetions (E 1) and (E 2) It wa found that:

$$
\beta_{A B}=\beta_{B}
$$




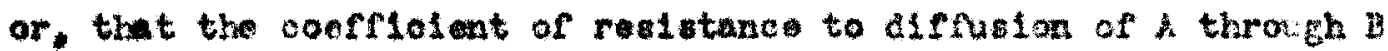

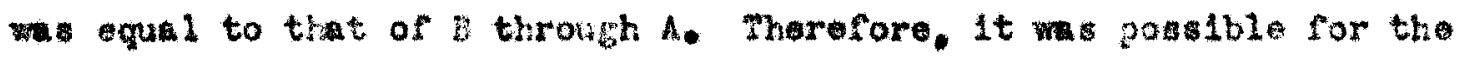

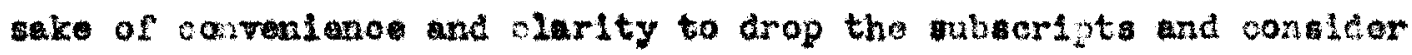

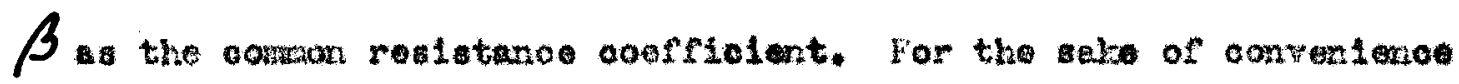

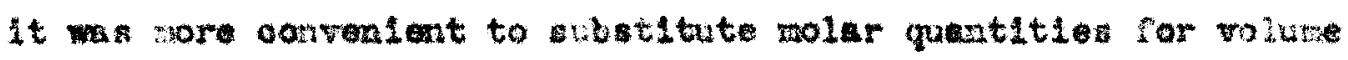
guant1ters.

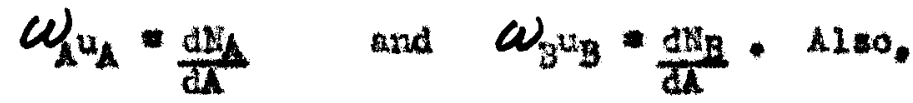

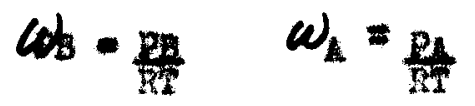

I Abolute tomporature

N Vivereal ocostant

Newriting oquations (E 1) and (2) tho expression

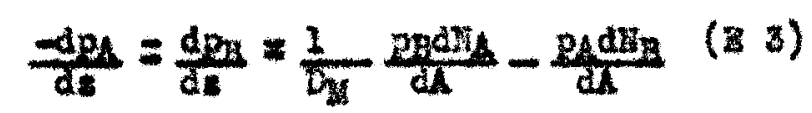

Dis. Dienuivity $\frac{\mathrm{pg}}{\mathrm{T}}$

For the sake of siapliolty in absorption work, the ball arount of inert ges. 3. which alrfuas as neglooted. If thore no net diffulom of the component 3 , then the value of dig wo zoro and equation (IS s) oould be ltteat

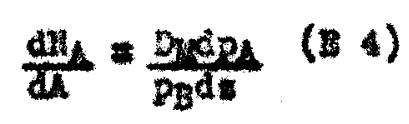

In the case of yotom which contulned only enall pereentages of the solute gac. the value of $\mathrm{PB}$ varied only slightly, and pB was oandiared

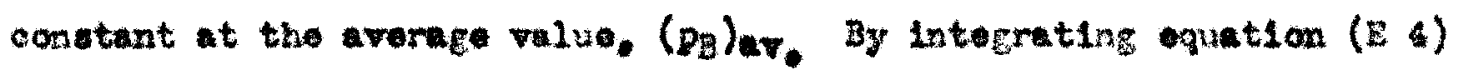

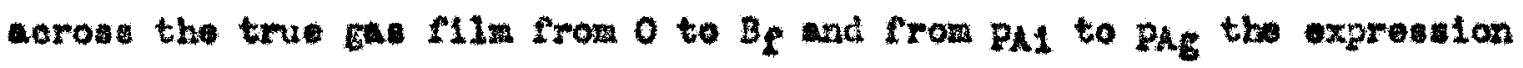
obtalned me: 


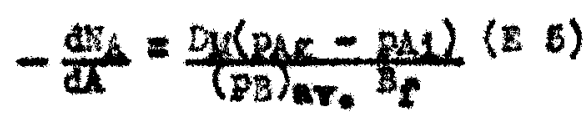

In the other ense where lere percentage of the solute was prestat

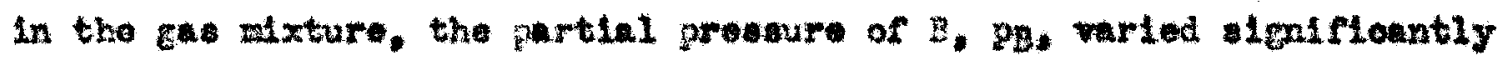

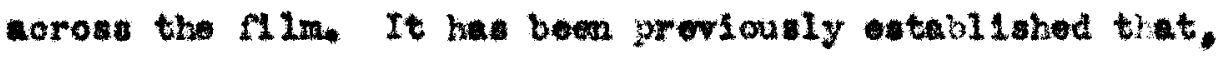

$$
\Delta P_{A}=d P_{2}
$$

therefore subetituting In equation ( 4 ) the equation obtainod wast

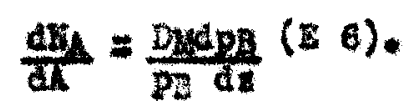

Dy interating ( $e$ ), the expression obtaknod was

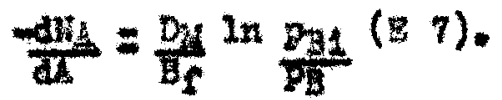

$$
\begin{aligned}
& \text { sinoe d } P_{A}=p_{A_{B}}-P_{A 1} \text { and }-a_{P B}-p_{B 1}-p_{B} \text { then }
\end{aligned}
$$

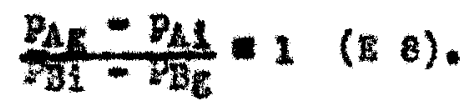

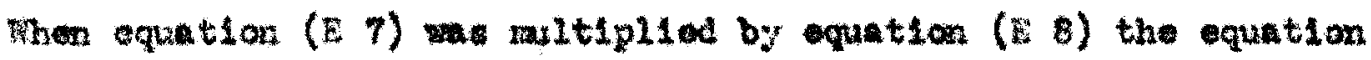
obtulnea mat

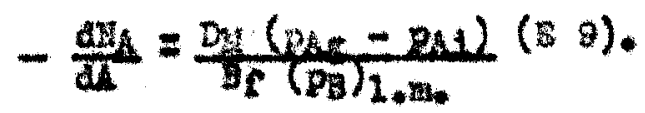

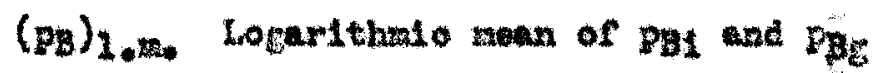

Tor enclneoring purposes it we corvenient to deteraine

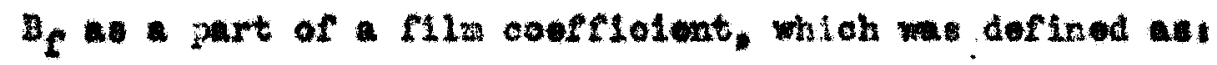

$$
z_{t}=\frac{D_{4}}{\left(D_{g}\right)_{1, B_{*}} B_{t}}
$$

Subst1tuting this coefriolut in equation ( $\mathrm{x}$ ) the expresalon obtalned was

$$
-\frac{d y_{A}}{d x}=k_{t}\left(p_{A_{5}}-p_{A L}\right)(E 10)
$$

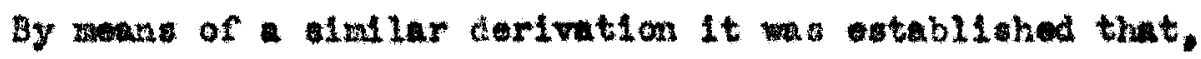




$$
-\frac{d u_{n}}{d a}=k_{1}\left(o_{A 1}-o_{A 1}\right)(11)
$$

$k_{1} \quad$ Liquid film oosflolent defin almiarly to $k_{g}$

Q Concentration of $A$ at the interface

al Conoutration of $A$ in the 11 quid

Inopeotion of aquation (E 10) and (2 11) showed that at -qual conditlone of oonountration of olute in the and in the

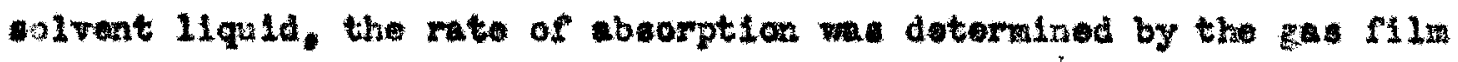
ooefrleleat, $k_{g}$ and the ligula flim coefflotent $k_{1}$ *

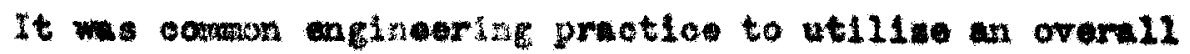
ooefflelent, $\mathrm{I}_{6}$ or $\mathrm{I}_{1}$ whlok took lnto nocount the resletance of the

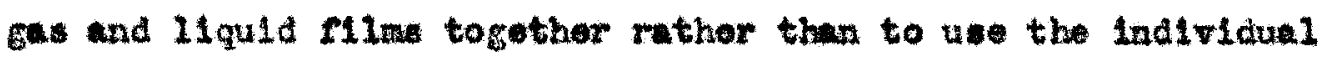
coefrlolute which took Into hocount ouly tho Individual resiotanoeu of as and 11quid fliss. In orter to use an oworall coefflatent. It wa noovenry to expreas the total difference botween the conou-

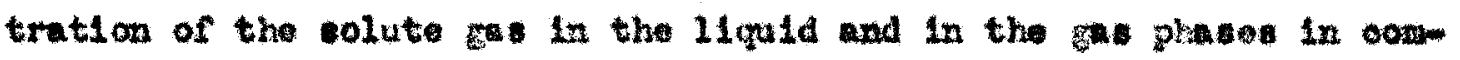
parkble unite. Aooordingly. the ooneentration of the wolute in

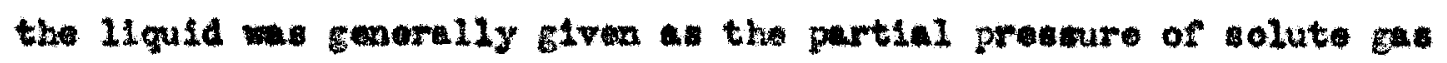

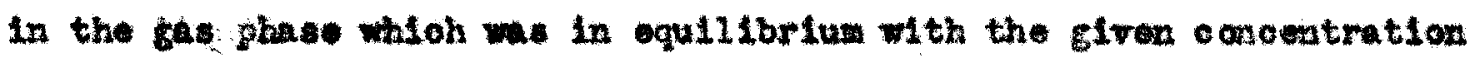
of the rolute in the olvent 11quid. This quantity wa danoted

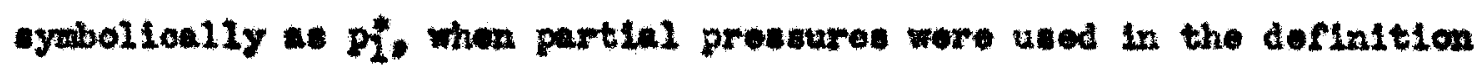

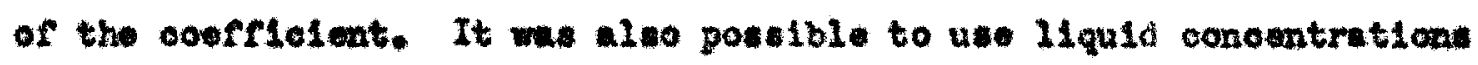
to exprese the relatlonshlps dealt with. Wu thls we dono, tho conemtration of the solute gas in the gas phase wa expresed as the conomtration of uolute in the liquld wiok would be in equilibrium wh the gas at that partid prosoure. This guantity was denotod 
oymollon $21 \mathrm{y}$ as of

$$
\begin{aligned}
& \text { Bquatlow (E 10) and (1 11) woro now writton, }
\end{aligned}
$$

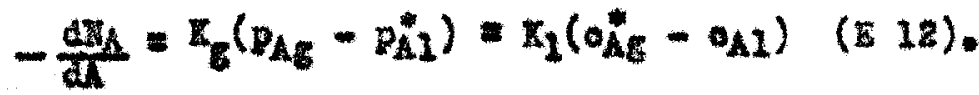

The overall ooefflelente wero oas1ly obtalned from the in-

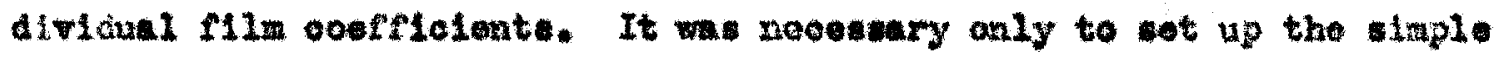
relationahp, $=$ no, where we the preportionality cometant of col-

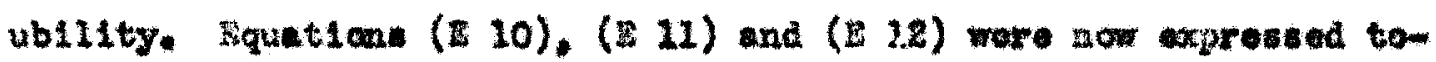
cother at:

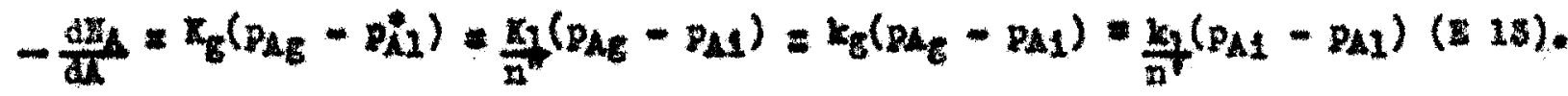

$$
\begin{aligned}
& \text { * } \quad \frac{\left(p_{A 1}-p_{A 1}\right)}{\left(o_{A 1}-o_{A 1}\right)}
\end{aligned}
$$

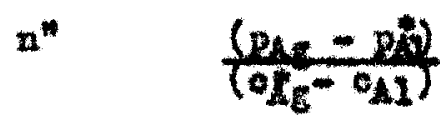

Solvine. the exprestion obtaind wa.

$$
\frac{1}{k_{c}}=\frac{1}{k_{6}}+\frac{2}{k_{1}}=\frac{n^{*}}{k_{1}}(24) .
$$

In the umal eave where the colublisty of the solut rad followed

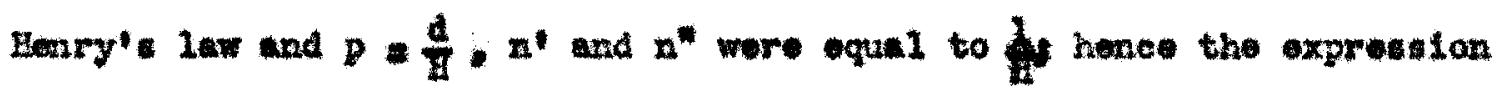
obtulned wist

$$
\frac{1}{x_{6}}+\frac{1}{1 x_{1}}=\frac{1}{1 x_{1}}(\mathrm{E} 25)
$$

It has been foum in pructice that the valkes of $k_{6}$ and $k_{1}$ a axpresed in equation (10) and ( 12$)$ wore quite often of the

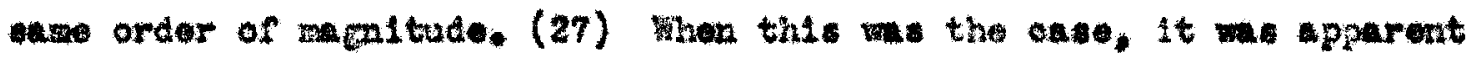

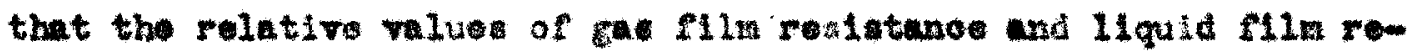

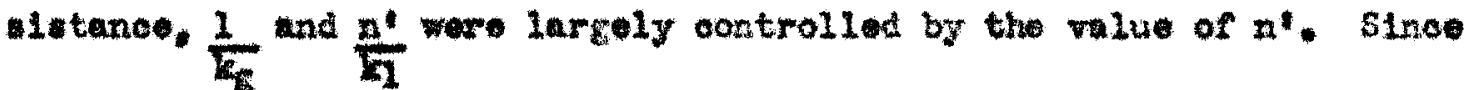
the value of at wa leteratned by the solublilty reletionshtps of the 
aytean, according to the cquation $p=n$ o. It we apperent that far gases whin were highly soluble in the solvent liquld that $n$ " would

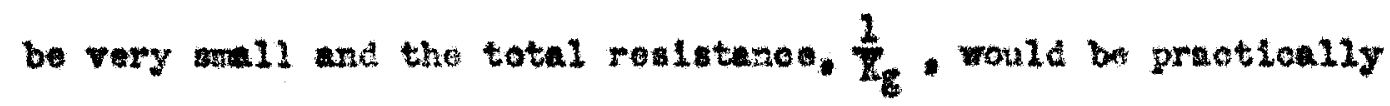

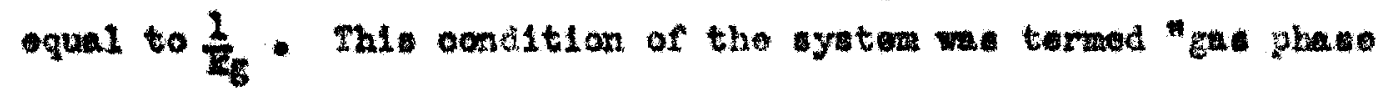

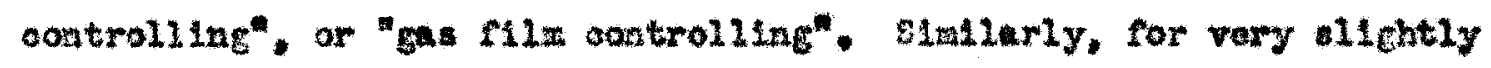
soluble gaves. $n$ " would be large and the total realotance, $\frac{1}{\mathrm{~K}_{\mathrm{C}}}$. would

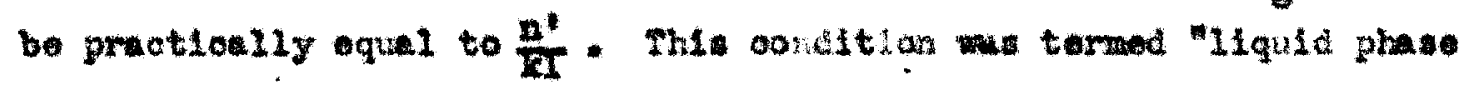
controlline" or "liquld flim controlling".

The syotem dent whis in this researoh, the systom carbon

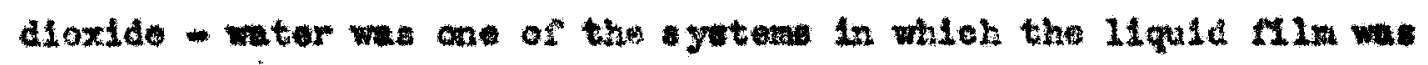
controlling. For that rasen, only the theory of absorption systom in wioh the llquid flu wo ocntrolline was dovioped further in this thases.

Any variable whoh would in any ray offeot the 11 quid fila

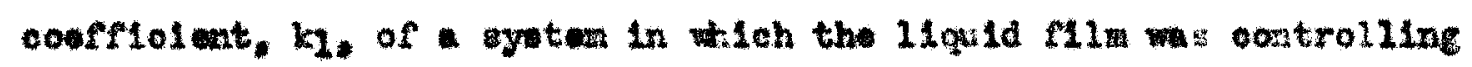

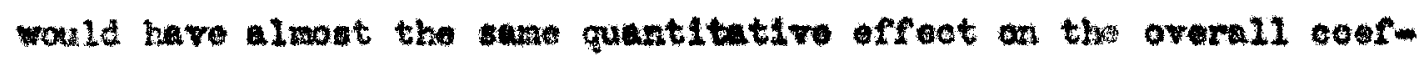

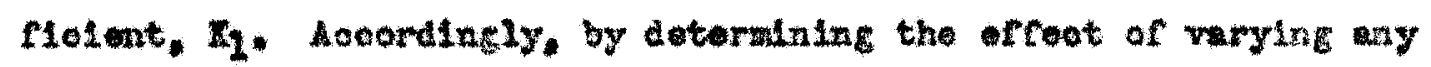

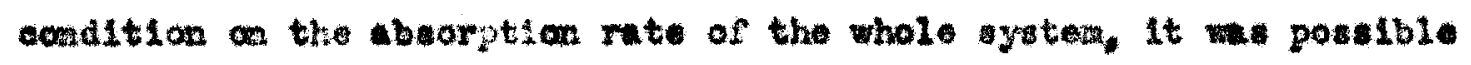

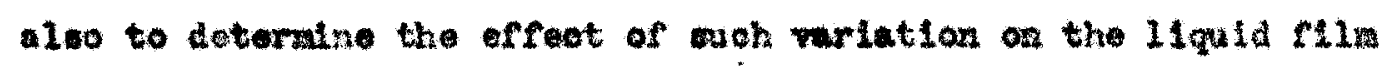
cooffletwat and on the 11quid flim.

The effect of the -1800sity of the solvent 11quid on $\mathrm{k}_{1}$

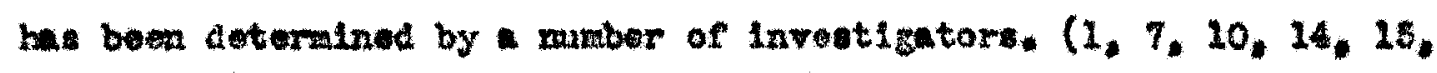
17, 18, 19, 20, 25, 25). The conolualon generaily arrivat at wat that the 11quid fild coefflolent wo Inveraely proportionn to the twothird power of the viscosity. This affect wo thought to be due to

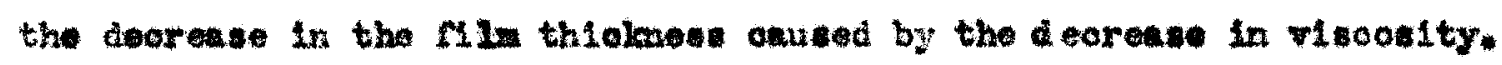


Increase in agltatlon, or inorwe in the rete of Now of the body of the fluld wo mothod by whoh the thickess of the rila wa redued. In canes where the 11quld Alowing dom the Inside

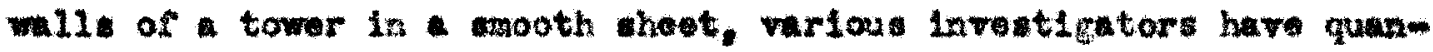
titetively determined the effect of lnorabe is the ralactty of the

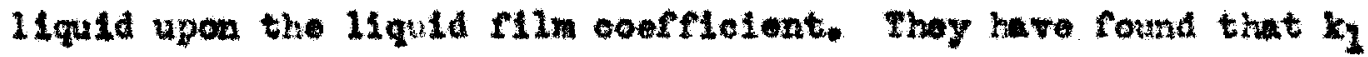
we proportional to the Alent-tenthe power of the roloosty of the 11qutd. $(1,2,3,8,11,14)$.

Ho raferenoe to eny provious lavectigation of the quantltative affect of vartation of the warface tenslan upon the Ilquid flin ooefflolont wa fouad. Thore wore found, howorar. two liuetons to the

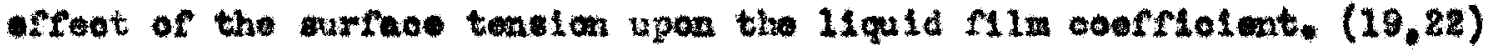

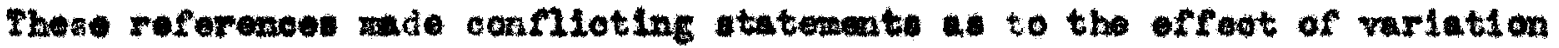
of surfuce tention upon the absorption rate.

In any 11 quid thare exitod a ourtain attruetion between the leoules of the 11quid. The attraotion smirested Italf neer the eurfues of the fluld where the nolecules were subject to an unm

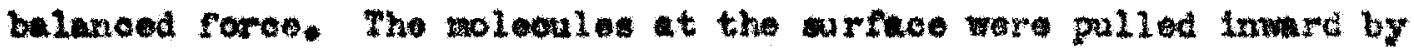
the nolecule below thes in the riuld and wore palled rrom all stden by the ettretion of tho woleales ourrounding then at the surfuoe. Howovar. thure we no pull exorted upon that from the ges above the 11quid curfuce. Therefore. the 11quid tended to ad fot 1teelf to the

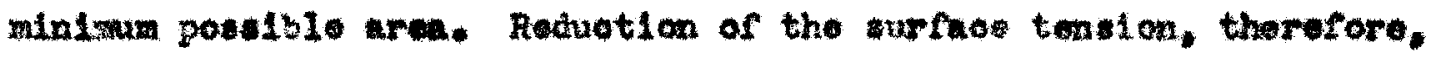

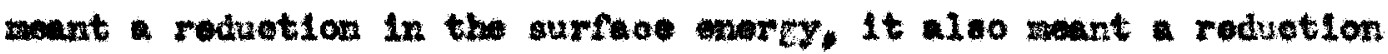

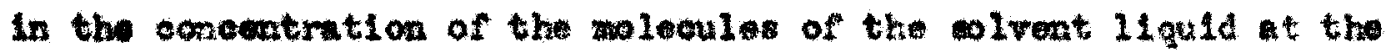

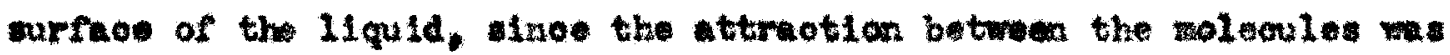




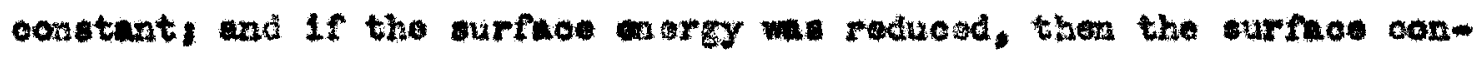
ocstration had to bo reduced proportiomally in orler to gre thia reduetion in surfaoe onergy.

The additoh of rarlous caterlal ta the solvant 11quid tended to decrease the surface temalon of the 11quid. Fhis was brought about by the aooumiation of the roleoules of the solute terial at the ourfaoe of the 11gu1d. tending to lowar tho surface comoentration of the solvent and thus to lown the surfece eargy of the solutlon. Very 11 guestitlen of oortaln wetting agente aooordingly ha very declded effect on the arface teneion of the wer. stnoe a raction of the onergy latalning the bonds be-

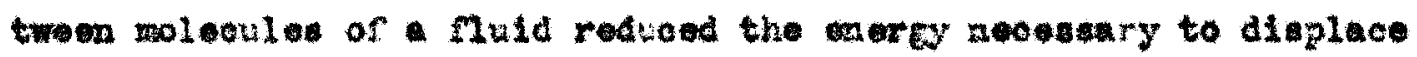
ane of the weoulos frow ito natural poutton in the fluld becuso of the deorease in the forees holdung then togethor it ppeared that

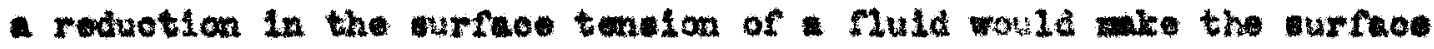
of the Muld more reciliy penetrated by a diffuelng gas. When the

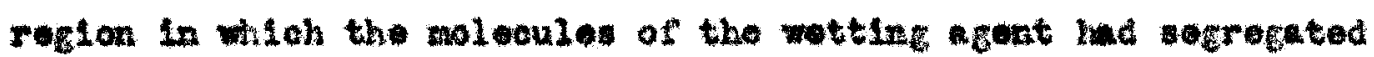

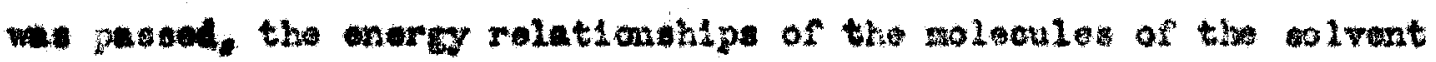

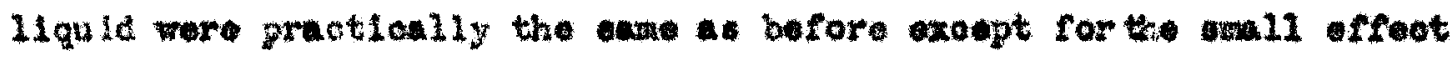

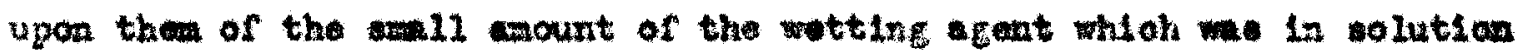
In the Interior of the Muld nase. The raduction of the curforoe oonoentration of the solvat liquid reaulted in a cirect reduotion in

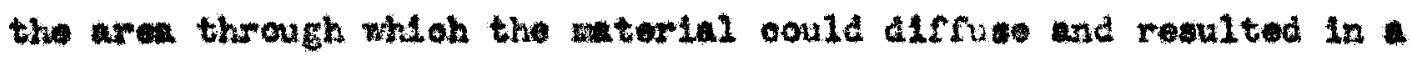
diroct reduotion of the rate of diffualon of the through the arrface

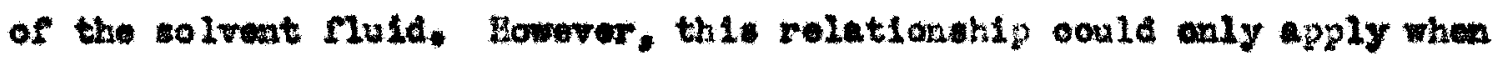
the colvte an wot soluble in the wotting agent used to raciuo the 
urface teasion of the solvent. In the flrot oase. In which the olute 18 Insoluble in the wottinc agent, it followed that the two erfect. of the reduction of the surface tention as explatned aro lad can-

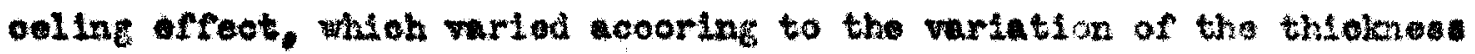
of the wurface rilm. In the secand oave. it follaned that the offect of reduction of surfuos enorgy could dismppons while the effect of

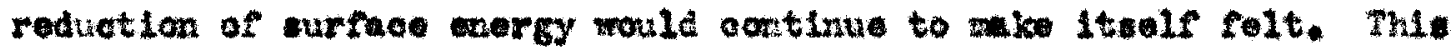
veriation in tho two aces noocunted for the virintion in the reparted afreot of wotting gente aborption rate, whoo observar (19) reported reoults obtalsed ustat butanol and the other observer (28)

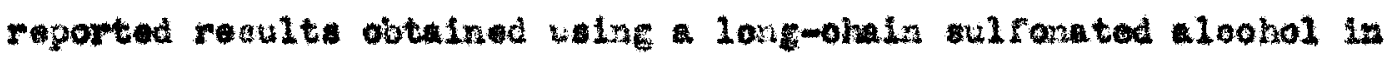
whioh the gat wa ineoluble.

The fnituce of the effoet of the reduotion of the wurfoot meriy of the solvent upon the rate of alffusien through the 11quld III depended upon the number of layer of nolwoules of solvent 11 quid mioh were contalned in the 11quld Mlin. In caver wher the 11quid

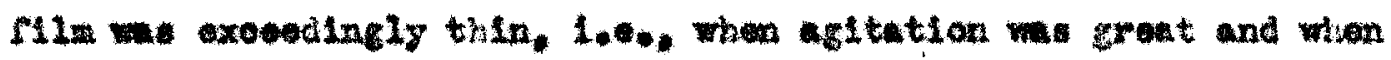

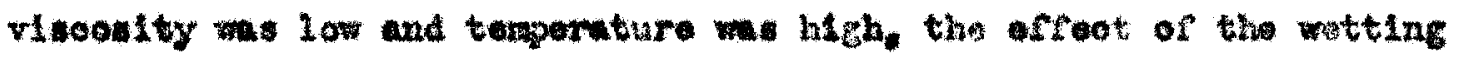

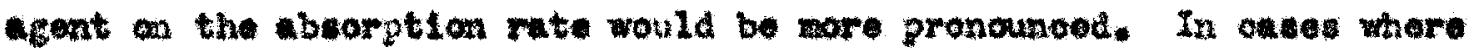

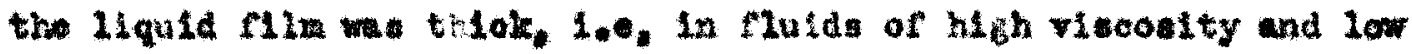
temporature wilch wore almot stagnent. 14 soemed that the offeot of the wotting agent would be miniminod.

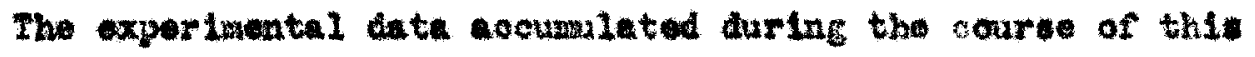
researeh 11 tends to verify the reaconing presented in the proceding paratrohs. llowever, the quantity of the expartanetat data was not

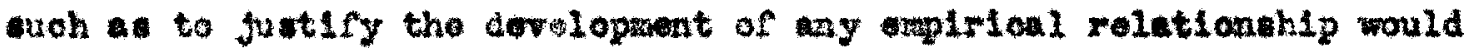




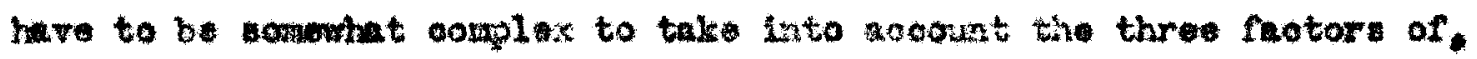

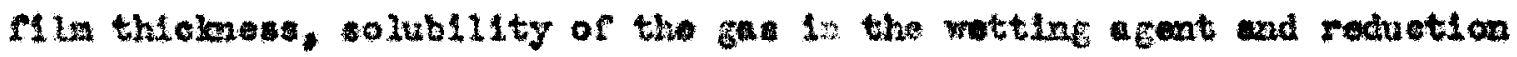
of surforo enery. 
BXPBRIVERTAL 
Leseription of Apparatu:

The apparatu* used in this rasearek a batoh absorption apparatus. Absorptice took plaos in the reaction vesel, J. witioh

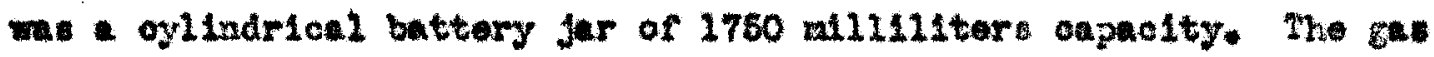
end the solution wore acteted by nean of a strrer. * having one pulf of blades in the solution and one par in the abowe the polution. The stirrer wa driven by aco drive stiring notor, $f_{\text {, at }}$ arying apeede of rotation. Projectin Into the resotion vessel was 50 pl1121ter burette, o, when wa used to titrate the colution. A

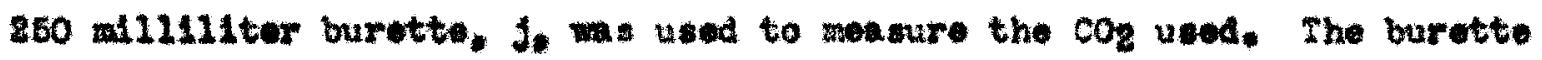

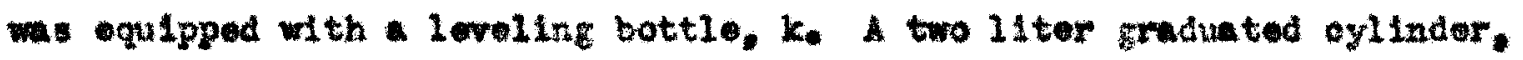
0. whlch we used to moature the water vedt wa oonneoted with th water reservolt. $b$. The temporature of the aolution in the reation

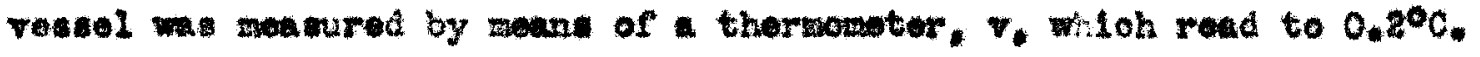

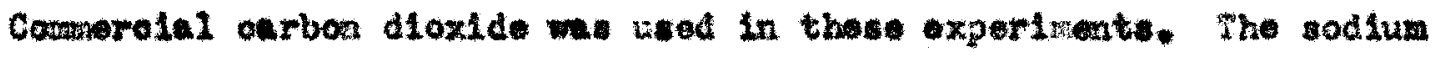
ourbonte ueed was tored in bottle, which was conneoted with the top of the burstte. The solution in the reation veseel wa neated by neane of a heting ooll, t. Wheh wa auplled wth lot wer by

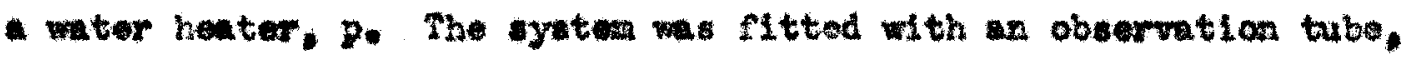
w. Where the tomperture of the hot water was ared. whe water bottle, b, the burette. * the codiun carbonate bottle, $c$ and the

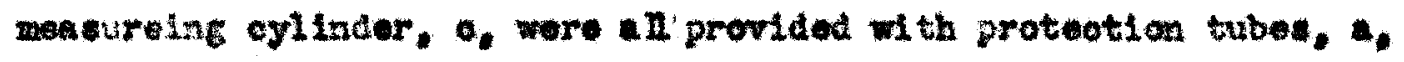

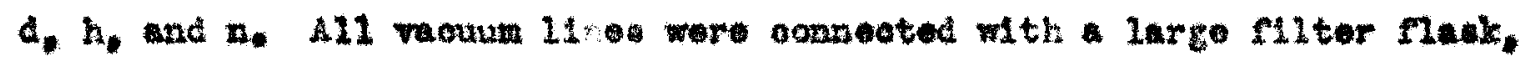
r. whioh aoted as a trap. All weter lines were conneoted with an obervation tube, g. The water lines woro all provided wth draing, wioh wore plped to the sink. 
TAEL I

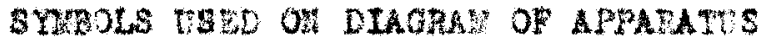

1. Proteotion tube

b. Watar storag bottle

a. Wearurlat oylinder for ter

d. Protoction tube

- Murott uaed to 1trate colution

f. stlrrer notor

6. Sodium carbonate torago bottlo

h. Proteotion tube

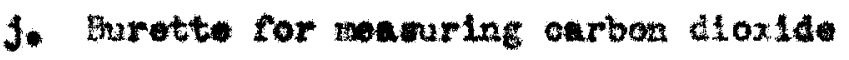

k. Level bottle

m. Obeorvation tube for weter in henter

n. proteotion tube

P. Water hetar

9. Obeervation tube for tor feed

r. Suotion Rask

- Stirrer

t. Venter cos

u. Remotion voavel

7. Thernomenter

W. Relenee ralre

x. Draln 


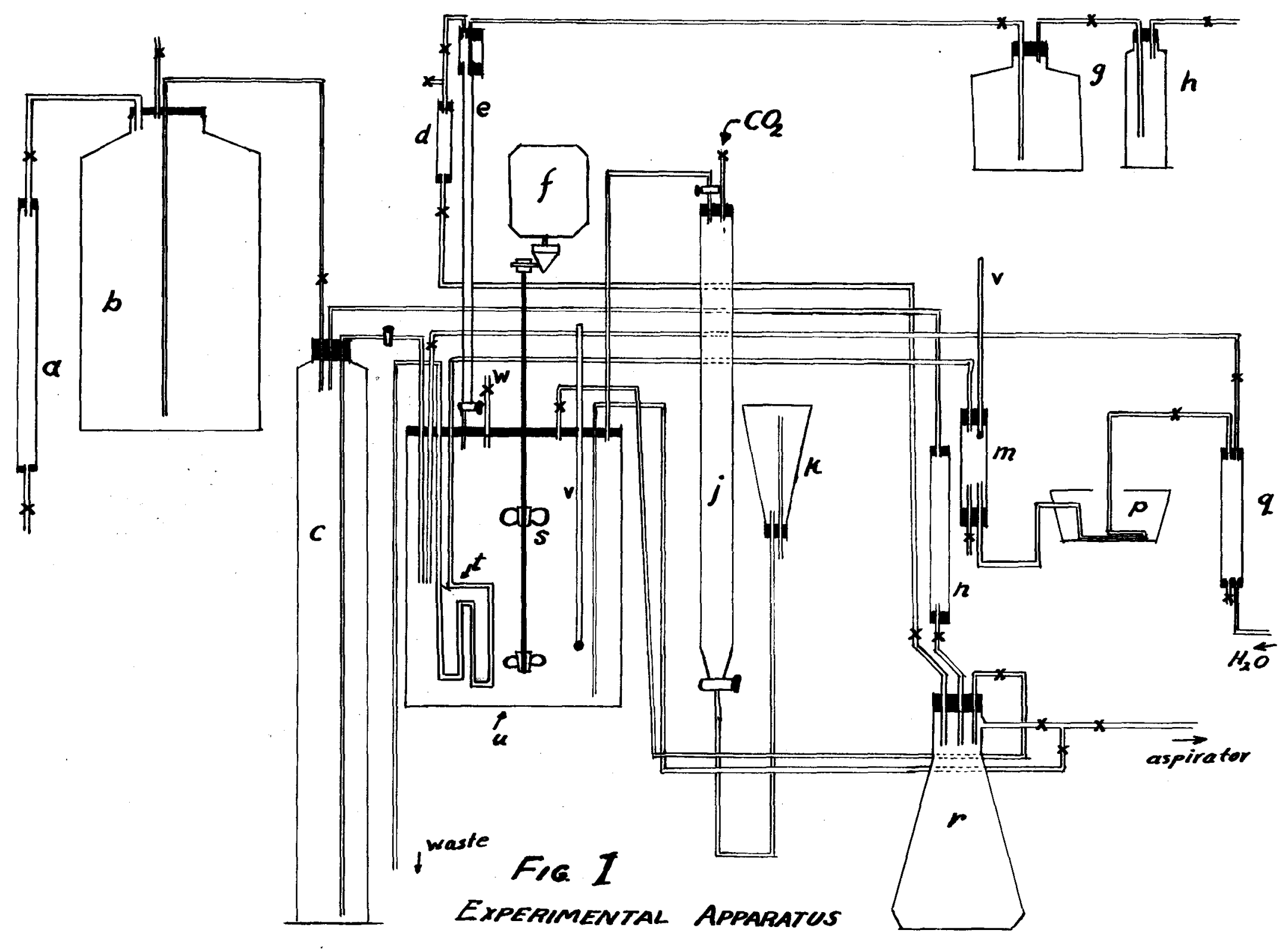

N 


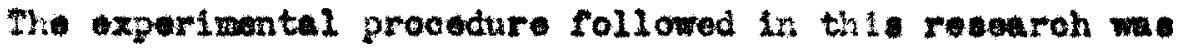
- atmple one dealnod to givo as acurat detoratration an ponatblo of the overall aborption conflelents by a nethod ouflolently rapld to pernit of the accumintion of a relatively iarge amount of experimental cata.

The batch syeter of absorption chosen 10 preferenoe

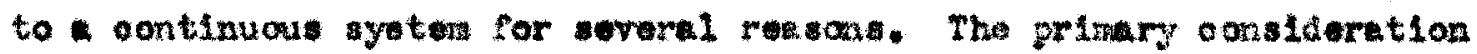
wa the the butch aystem did not require long period of operation durling winloh the syeten wa allowed to renoh ocullibrum bafore data

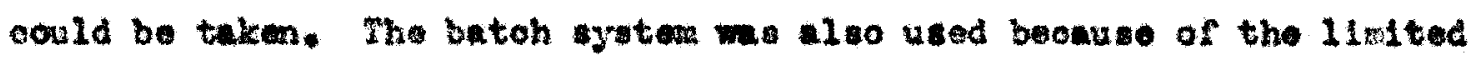

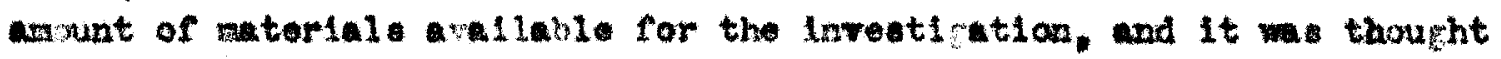
that the bateh oyotan would require mich las material than continuou systan.

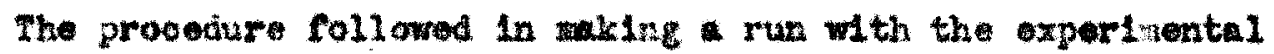
apperatus used wa brierly as follows: Ife hudrit nilliliters of mater contalning the wottlag acant anc a mall anount of phenolphthalein

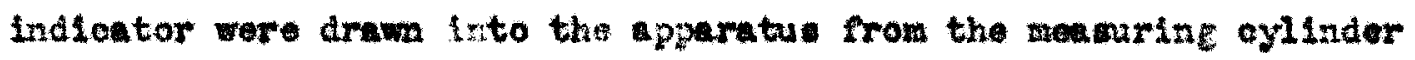
by moans of suction aplled to the absorption vessel by an asplrator. The agtutor we then turted and hot water from the hotor nu through the anil co11 on the Inelde of the untt. When the 11quid in the unit had roched teaperature of $25^{\circ} \mathrm{C}$. the coll was disoomested and the aftation stopped. The 11quid mo thon allowed to tand for ane minute

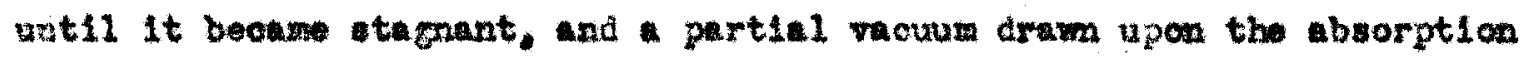

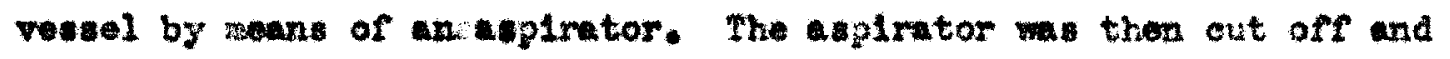
the IIne from the menuring buratte opened, and 200 illiliters of oarbon doxido gas wa Grawn into the yoten. As soon as the required 
anount had been added, the relowe valve was opened momentar11y so

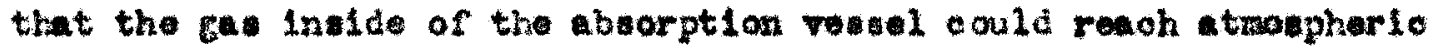
presare. The afitator we then atated and the time of aglation - locely controlled by umeans of a top watoh. Imodiately upon termintion of the period of gitation the releane valve opened, and a ourrent of alr wa drawn through the beorption vesel by mons of an avpirator. Thia ourreat of alr wa allowed to Mow through the venel for at least one minute oo that the sarbon diaxide could be ffectively

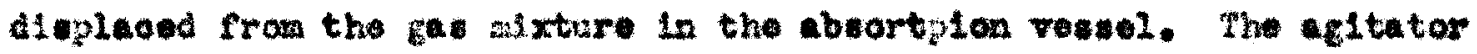
we then atarted agein and the 21 gula inslde the reasel titrated with tenth noranl sodiun carbonnte solution. The ond point (21) ma taken to bo the appearance of the first plnk coloration of the liquid wioh would encure for period of one minute. At the end of thes tims, the

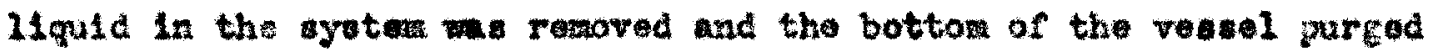
w th averal wallquantitles of the liquid as to be used in the next run.

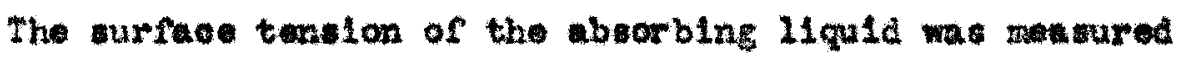

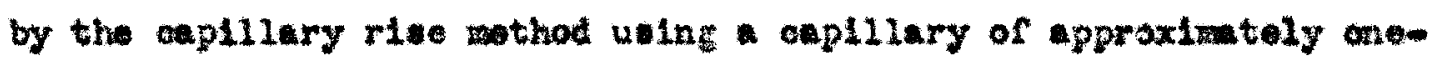

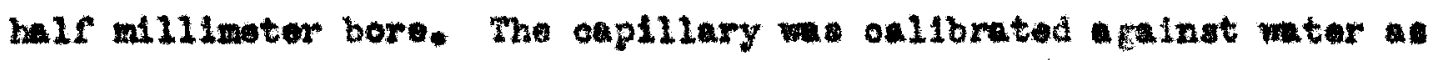

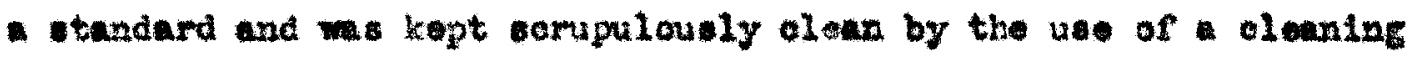
colution compos of concentrated onlphurlo acld und potantum d1ohromete.

The water used in the experimental work ofreed from ourbon d1oxide by drawize oarbon doxide free alr through it for perlod of thas of at lonet ane hours After this 1t wa protected from contaot Wth the atmophere by a tube fllled wh sodum hydroxide. 
The tanth normal sodum carbonate colution usod to titrete the wolution wh corefully propared rom reagent grade sodius carbonate. During the course of the resouroh it wa carenily protected fron

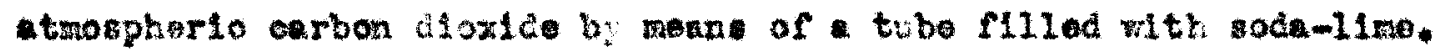

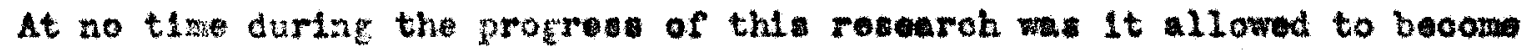
unprotected.

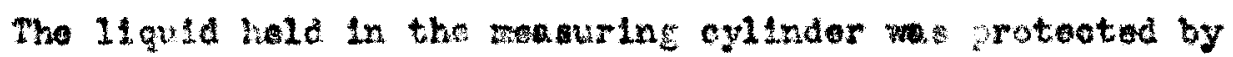

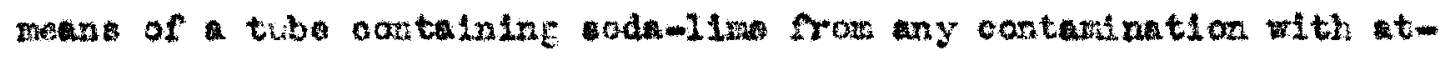
mospher lo carbon-dioxide.

The solutione of the weting conterten wero ved to decreave the orfuce tensian of the aborbing liquld wore carofully tented to detersine that thoy wero not old or besto in thelr renction whth ter.

A serian of blank titrations mo rus to deternding the anount

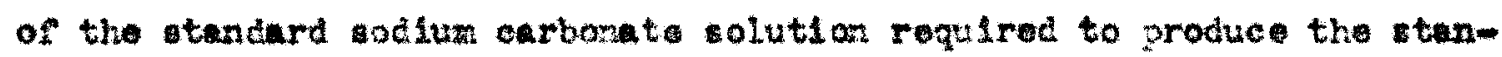
dart Indicator change when allparts of the prosedure vere ourried through except for the perlod of afitation. A ceries of blank were 1so run on the aolution ued whout llowing then to come into

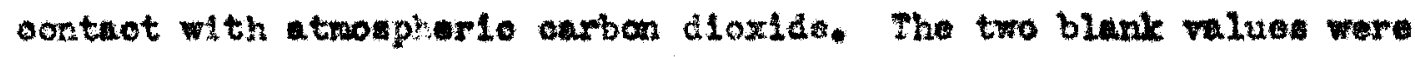

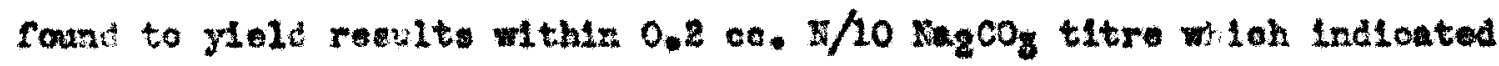
that there wa no cause to fear any wenrablo aborption of curbon doxlde curlnt the pertod when the olution stood tagnent. Thl wa

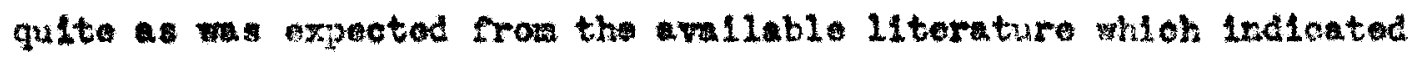
that the rate of aboorption of curbem dloxide Into the mater when atmonat very low. 
anta 
The data obtalued for onch veriation in ourface tension and In rete of aftation wor avaraged and gumarised. The tabulation of these ausaried date was presented in Table II. The enter in t. 1s table represented the bosorption rate in moll of carbon diaxide

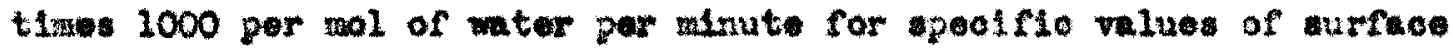
tenslon. They wore arrazged in the table accordine to wotting agent uned and agtation rate apployed. Ine dath prosented wore those for

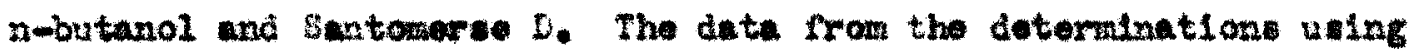
Aerosol and 18o-pentunol wore not prosented fno they wore run only as oheoks the data for suntomeres $D$ and n-butanol in order to estublish the fact that the ourves were typloal of the type of wetting agent uewa.

The date obtalnod for Aeroeol ylelded raulte olntlar to those obtulned for Santomerwe D, while those obtained for isompentanol gave results similar to those obtined from the detormintions using n-butanol.

The data presented in tebuler form in rable II were plottad In Figures 2 and 5 , the data for santonerse $D$ being plotted on flure 2 while thos for n-butanol were plotted on ligure $s$. on the flgures. abtorption rato wa plotted galnet aurface tenclon of absorblag 1. โุนเล.

These ourves, in the onse of Santoworse is howed that the absorption rate deoreased Ith decrease in ourfuce tension up to

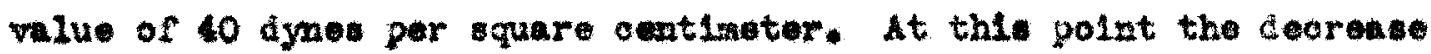
wa aproximetely 30\%. They showed that the woorotion rate inoreased about $40 \%$ with the firat adation of butmol or 1 sompentanol and con- 
tinued to fnorouso gracually wh oontinued decroaso of surface tombion unt11 an lnoreas of approxinately $60 \%$ we reached at a value of 40 dynes per square contlimeror. All the deta obtained were obtalned by the proooduro at ined 1n the precediagereotion of this thesis. 
TABLE II

SUMARY OF ABSORPTON DATE SAM

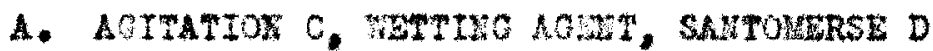

\section{Surfuce Tengion Dymes/ona 2}

70.0

57.6

49.0

46.5

45.0

59.0

27.0

$23_{.} 0$

22.0
Abtorption shto Holl $\mathrm{CO}_{2} \times 10^{3} / \mathrm{min}$. per mol water

0.228

0.196

0.182

0.176

0.162

0.144

0.144

0.157

0.258

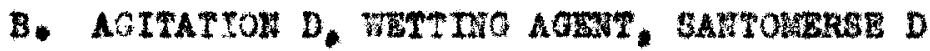

\section{Surfece Tansion Dymes/onat}

70.0

81.8

60.0

84.0

31.0
Abeorption Rate HoLe $\mathrm{CO}_{2} \times 10^{3} / \mathrm{min}$. per mol water

$$
\begin{aligned}
& 0.252 \\
& 0.231 \\
& 0.208 \\
& 0.216 \\
& 0.859
\end{aligned}
$$


TAPLE II COH'TELD

SULUEY OF ABSORPIOL NAL WAA

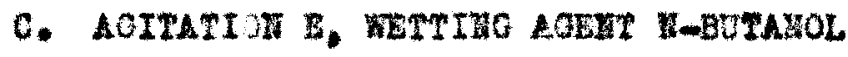

\section{Surface Tengloa Dynes/os. 2}

70.0

68.0

E7.

52.0

48.0

30,0

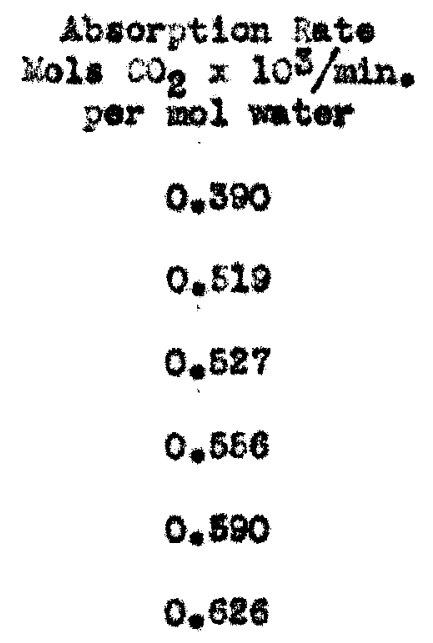

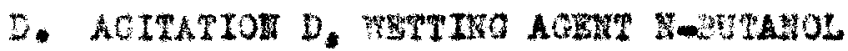

Surfaco imglun
Dyneo/on.
08.0
61.0
56.0
4.0
42.0

Absorption iato vols $\mathrm{CO}_{2} \times 10^{3} / \mathrm{min}$. per ol wer

0.34

0.344

0.550

0.363

0.369 


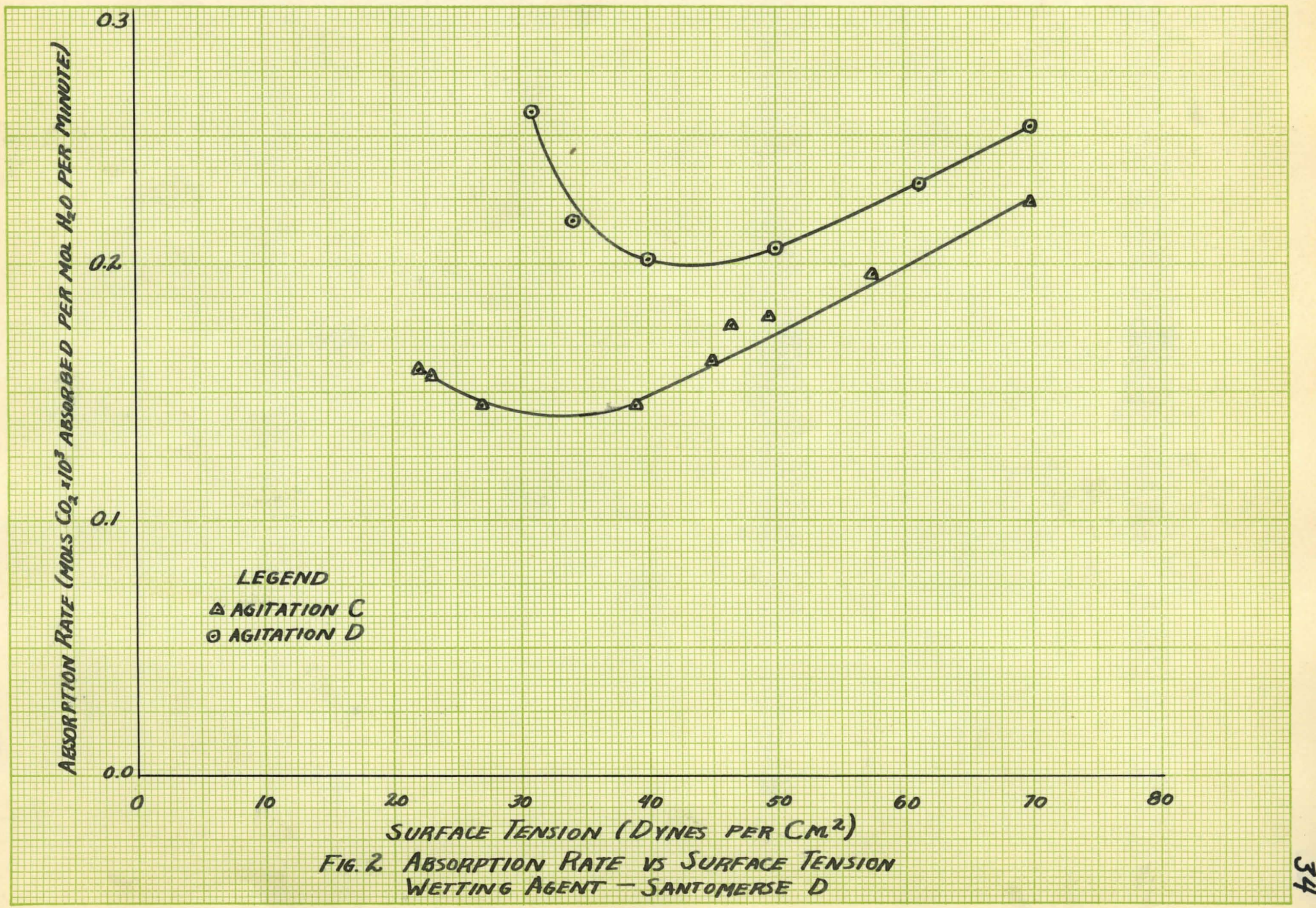




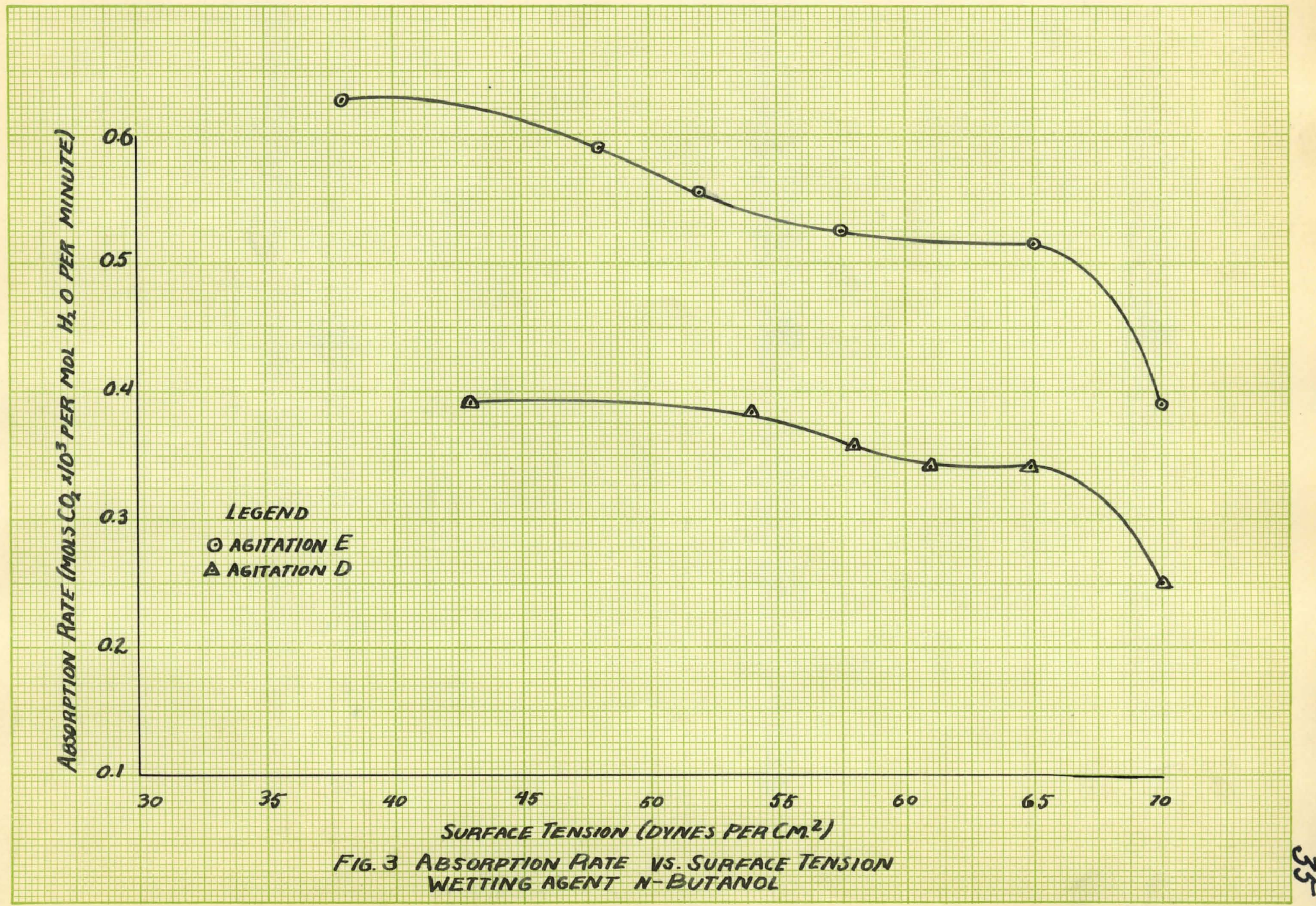


IXTERTERATION ON MANA 


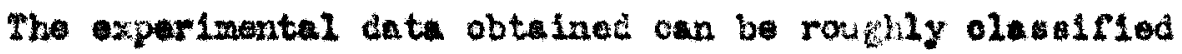
Into two eroups. Wheso aro. 1. The data obtaliod for absorgtion rate

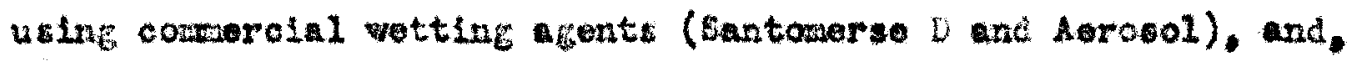

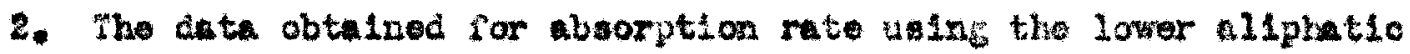
acoholo (n-butanol and sompentanol).

The at 1 ronated alcohol of high zalooular welght which were

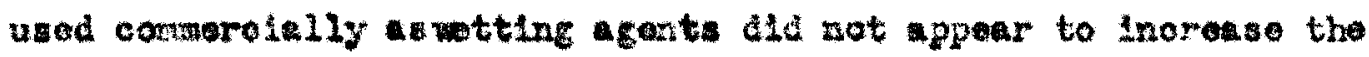
absorption rate of ourbon dioxide in wer. Oper the highor range of surface tonsions. the boorption rete acroused almot ln diroot proportion to the ceorense in surface tanion. When eurface tomolon was further decreased, the abouption rate inoroused. Ihe we of ordinary allphatio alooholo apponred to realt in an inorace in absorption rate.

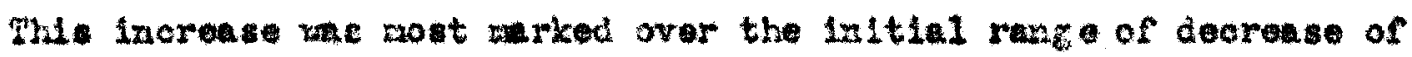

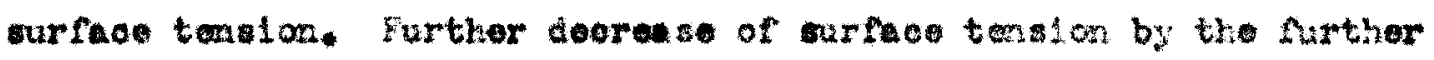
adation of wetting gont resulted in a contlnued riso in aborgtion rate.

There we not found in the 11teraturo invedt gatod any data

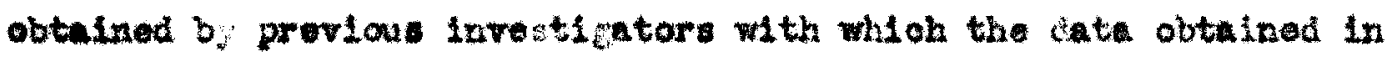
this research oould be quantitatively corrolated. Reav and Bohro (10). state thet the nee of oertain 14quids whiol lower the surface tenlon appere to inorease the aborption rate. Sherwood and Iollony. (22).

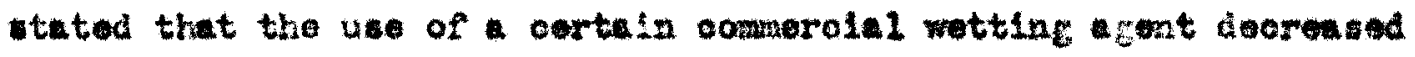
the abuorption rate. In nelther aee is there any quantitative data prosonted. 
CowCLUS IONS 
It appeared thet the varlatione in abeorption rato observed depended not only upon the aurface tenalon but alao upon the nature of the wotting agent used.

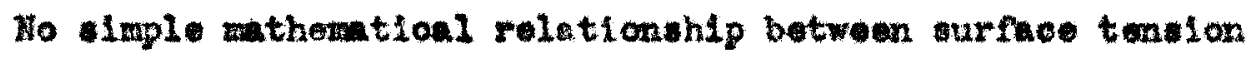
anc absorgtion rate conld be corrolated from the data obtairied.

Corrolation would woera to depend on obtalning largo gum-

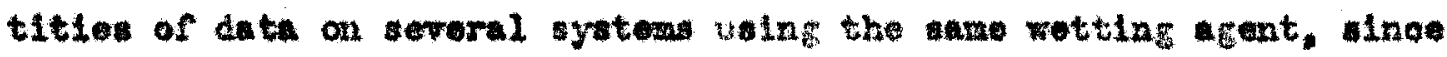
the properties of the wattinc agent itwalf hud a great affect on the absorption rate. The wetting egento in which $\mathrm{CO}_{2}$ was ineolubel lowerod the aborption rete, whlle the wettin agents used in whioh $\mathrm{CO}_{2}$ wa soluble Increased the abuorption rate. 
APPEODEX 
SALYLE CALCOLA IOHS

The only onloulation: mde, other than the rary simple elementiary ones, were the caloulatione for hrface tension and nol of ourbon dioxide per wol weter in the olution at the end of the man.

Surfeos Teation:

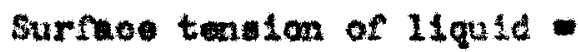

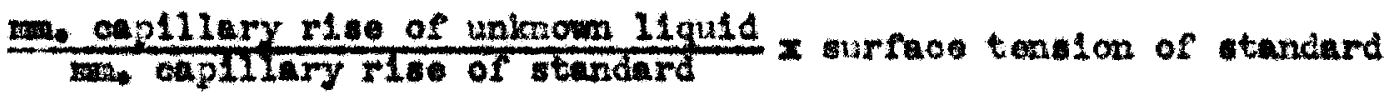

Wols of Carbon Lioxido por nol of weter!

Lola of carbon dioxide per mol of met a

(mi. Inacos t1tre) (narmality of Hancos) (molo $\mathrm{z}_{2} \mathrm{O}$ (1000) 


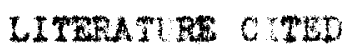

(1) Adum, F.H., Ind, Zng, Chem, 25, 424-128, (1938)

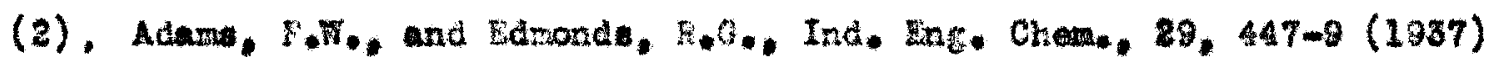

(3) Aatrosohonko, V.I., J, Applied Ches. (U.8.8.R.). 12, 167-80 (1939)

(4) Baker, 2, H., Trant, A, I, Ch, 1, 15, 196-216, (1225)

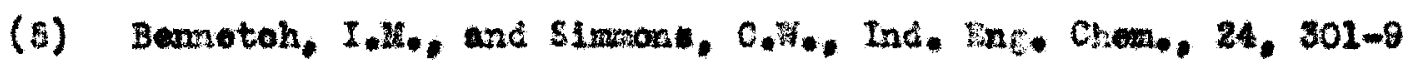
(1932)

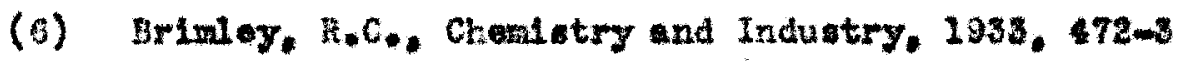

(7) Colburn, A.P., Ind, Dag. Chen, 22, 967-70, (1950)

(8) Contook, C.8, and bodge, 3, F, Ind, Bhg, Chem, 29, 620-9 (1937)

(9) Dav18, 5,3, Ind, Ing, Cham, 25, 1023-6 (1983)

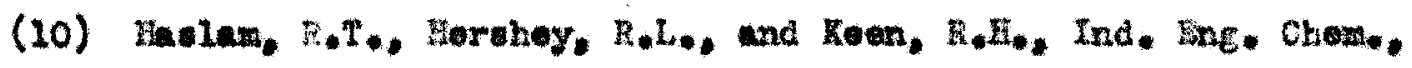
16. $1224-30 .(1924)$

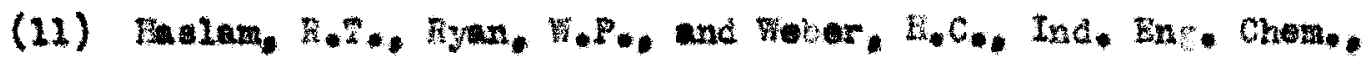
15. $1106-8,(1923)$

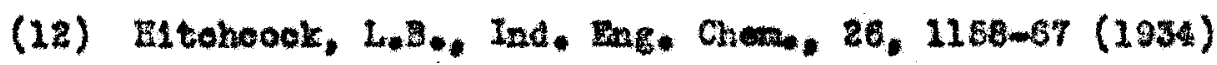

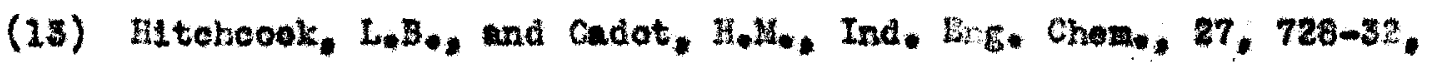
(2935)

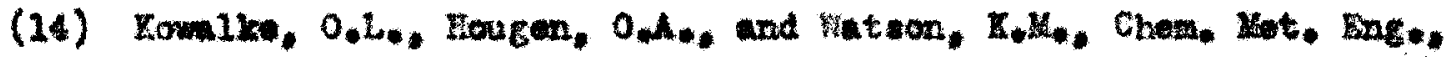
32. $506-510(2925)$

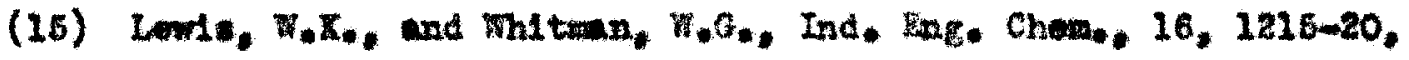
$(1924)$

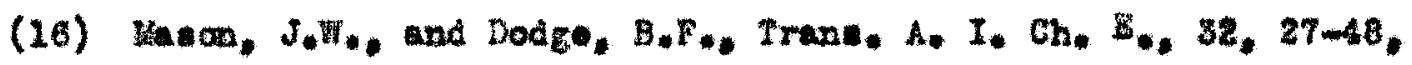
(1946)

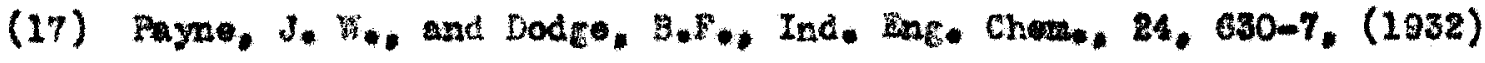




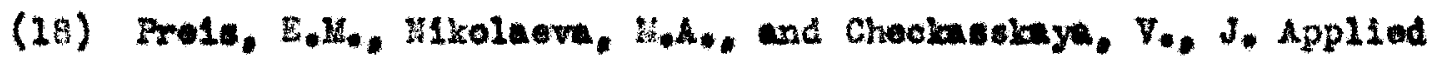
Chem. $\left(0, s, 8, n_{*}\right), 0,2179-99(1936)$

(19) Reng, $H_{0}$, and Behre, $\mathrm{C}$, , Kollold-2, $71,129-45$, (1985)

(20) R1ou, P., and cartier, P., Compt. rend., 186, 1700-7, (1928)

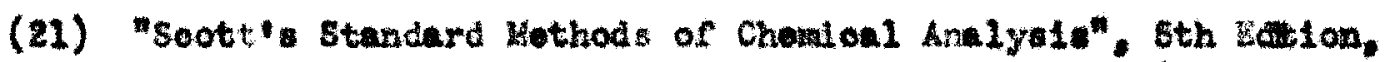
PE. 2075, Kew York, D. Van Woutrand Compuny. 1959.

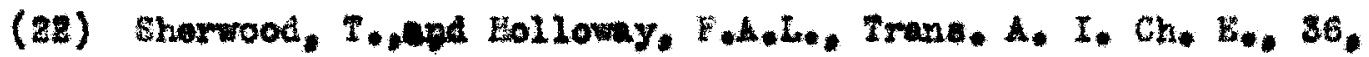
21. (1940)

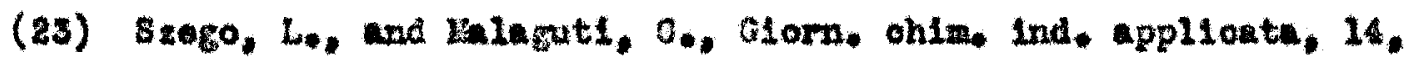
12-18, (1982)

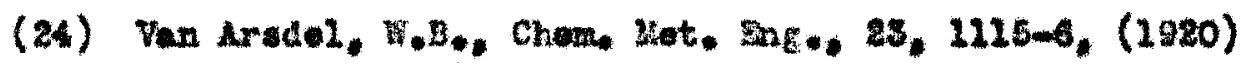

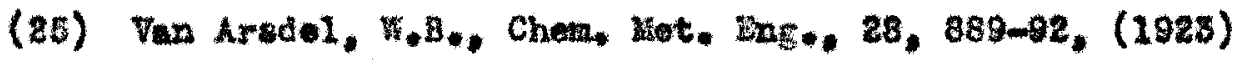

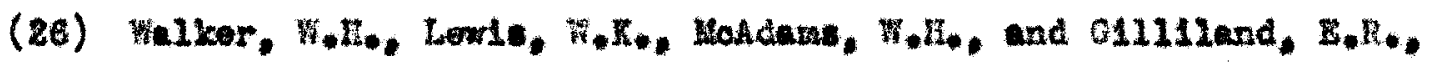

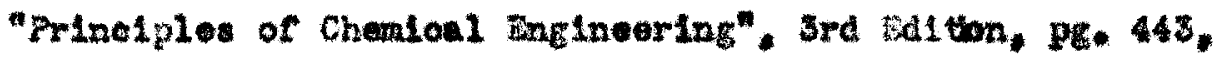
Hew Tork. HoGrum Hill Book Compuny

(27) 1bla, $\mathrm{PB} \cdot 46 \mathrm{~g}$

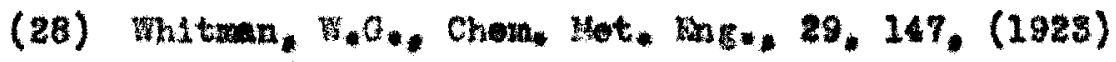

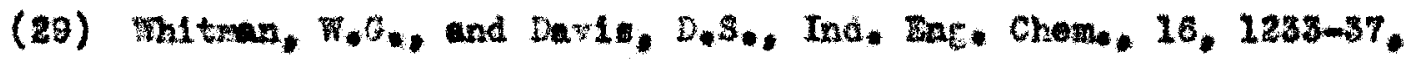
(1924) 
Fune 1 to 32 porformed oa the problew woro trial mu and onziot bo included with the experlinental data hero tubuleted.

In 11 coses. 500 mililltar of the absorbing wolution were used in the reaction vasuel.

In 11 osos, the peromtage of carbon dioxta in tho gat

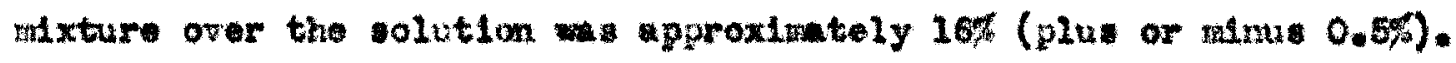


TABLE III COMPLES LATA

\begin{tabular}{|c|c|c|c|c|c|c|c|}
\hline Nun & $\begin{array}{l}\text { avetelng } \\
\text { Agent }\end{array}$ & $\begin{array}{l}\text { Agitation } \\
r-p=m .\end{array}$ & $\begin{array}{l}\text { Surfuce tonglon } \\
\text { Dyeateres }\end{array}$ & 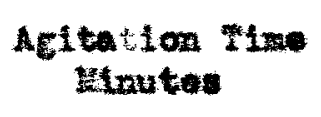 & $\begin{array}{l}\text { Temperature } \\
\text { Degroes } \mathrm{C} .\end{array}$ & $\begin{array}{l}\text { 21. } \mathrm{Ea}_{2} \mathrm{CO}_{8} \\
\text { par } 500 \mathrm{cos} \text {. }\end{array}$ & Isols $\mathrm{co}_{2} \times 10^{3}$ \\
\hline $38 \mathrm{~A}$ & Aerosol & 800 & 47.0 & 5 & 21.0 & 7.80 & 0.497 \\
\hline 34 & Aerosol & 500 & 47.0 & 5 & 22.6 & 7.50 & 0.475 \\
\hline 354 & Lerosel & 500 & 47,0 & 4 & 20.5 & 7.50 & 0.475 \\
\hline sat & Aerosol & 500 & 17.0 & 4 & 21.8 & 7.80 & 0.497 \\
\hline 374 & kerosol & nta: & rus walried & In the prolintr & ary anipula & thons. & \\
\hline 384 & Aerosol & 460 & 21.5 & 8 & 25.0 & 17.20 & 1.175 \\
\hline 390 & Aerosol & 100 & 21.5 & 5 & 25.0 & 14.70 & 1.000 \\
\hline 400 & Seroed & 100 & 21.5 & 5 & 24.8 & 18.30 & 0.698 \\
\hline 410 & Aerosel & 100 & 21.6 & 5 & 24.5 & 13.30 & 0.898 \\
\hline 420 & herosol & 100 & 21.6 & 8 & $24: 3$ & 9.70 & 0.638 \\
\hline $43 C$ & Aarosol & 100 & 21.5 & 3 & 24.5 & 9.30 & 0.605 \\
\hline$\$ 4 C$ & Aerotol & 100 & 21.0 & 3 & 25.0 & 8.50 & 0.677 \\
\hline $45 C$ & Aerooul & 100 & 22.5 & 3 & $2 \varepsilon_{*}^{2}$ & 9.90 & 0.577 \\
\hline $46 C$ & Aorosol & 100 & 21.5 & 2 & 24.7 & 7.30 & 0.462 \\
\hline 470 & Aorosol & 100 & 22.5 & 2 & 24.6 & 7.10 & 0.477 \\
\hline
\end{tabular}




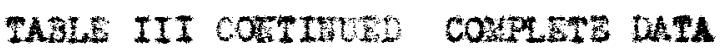

\begin{tabular}{|c|c|c|c|c|c|c|c|}
\hline Kum & $\begin{array}{c}\text { Tettine } \\
\text { hesent }\end{array}$ & $\begin{array}{l}\text { Agtation } \\
\text { r.p.tal }\end{array}$ & $\begin{array}{l}\text { Surfuce tomalon } \\
\operatorname{Dyzes} / \mathrm{cm}^{2}\end{array}$ & $\begin{array}{c}\text { Agttation rima } \\
\text { Hinutes }\end{array}$ & $\begin{array}{l}\text { Derperature } \\
\text { Degroes } \mathrm{C} \text {. }\end{array}$ & $\begin{array}{l}\text { 1. } \mathrm{H}_{2} \mathrm{CO} \\
\text { per } 500 \text {. }\end{array}$ & $\begin{array}{l}\text { wol } \mathrm{CO}_{2} \times 10^{3} \\
\text { per mol wer }\end{array}$ \\
\hline $40 C$ & orosol & 100 & 21.6 & 2 & 24.8 & 7.20 & 0.458 \\
\hline 490 & Atroed & 100 & 22.6 & 1 & 24.8 & 4.00 & 0.223 \\
\hline $\mathrm{EOC}$ & Aerosol & 100 & 21,5 & 1 & 25.3 & 4.05 & 0.227 \\
\hline b1C & Lerosol & 100 & 21.5 & 1 & 25.2 & 2.70 & 0.201 \\
\hline $52 \mathrm{C}$ & Aerasal & 100 & 22.8 & 0 & 25.2 & 0.00 & 0.000 \\
\hline $5 x$ & Loreaol & 100 & 21.5 & 0 & 25,2 & 0.66 & 0.000 \\
\hline $54 \mathrm{C}$ & Aerosel & 100 & 21.6 & 0 & $25 \cdot 2$ & 0.76 & 0.000 \\
\hline $55 C$ & herosol & 100 & 21.5 & 4 & $24: 5$ & 9.80 & 0.641 \\
\hline $86 C$ & Aerosol & 100 & $21 \div 5$ & 4 & 24.6 & 9.90 & 0.648 \\
\hline 570 & feromol & 100 & 21.5 & 4 & 25.8 & 9.40 & 0.613 \\
\hline 580 & Aerosol & 100 & 21.5 & 5 & 24.6 & 9.70 & 0.633 \\
\hline $59 C$ & kerosol & 100 & 21.5 & 5 & 25.0 & 11.00 & 0.735 \\
\hline $50 c$ & hero:ol & 100 & 21.5 & 5 & 25.0 & 0.80 & 0.619 \\
\hline onc & Aerosol & 100 & 21.5 & 4 & 25.0 & 6.60 & 0.554 \\
\hline 620 & Aarosol & 100 & 21.5 & 3 & 25.0 & 7.30 & 0.462 \\
\hline
\end{tabular}




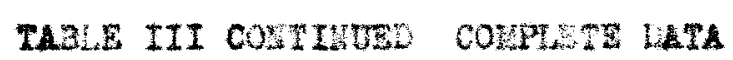

\begin{tabular}{|c|c|c|c|c|c|c|c|}
\hline $\begin{array}{l}\text { Tun } \\
\text { Suraber }\end{array}$ & $\begin{array}{l}\text { Fetting } \\
\text { Ageat }\end{array}$ & $\begin{array}{l}\text { Actation } \\
r \cdot p \cdot x\end{array}$ & $\begin{array}{l}\text { Surfoce tonglon } \\
\text { Dynes/os. }\end{array}$ & $\begin{array}{l}\text { Agtetion } 1 \text { ine } \\
\text { Zenutes }\end{array}$ & $\begin{array}{l}\text { Tenpereturo } \\
\text { Defreas } 0 .\end{array}$ & $\begin{array}{l}\text { 11. Wa2cos } \\
\text { per } 500 \mathrm{cc} \text {. }\end{array}$ & $\begin{array}{l}\text { Kol: } \mathrm{CO}_{2} \times 10^{5} \\
\text { por } 0^{5} \text { ter }\end{array}$ \\
\hline $8 s c$ & Aerosol & 100 & 21.5 & 2 & 25.3 & 6.90 & 0.510 \\
\hline 640 & A6rosol & 200 & 21.5 & 1 & 25.7 & 5.80 & 0.358 \\
\hline 650 & Lerosol & 100 & 52.4 & 4 & 24.6 & $\longrightarrow$ & - \\
\hline 860 & Aeroeal & 100 & 5.4 & 4 & 25.0 & 0.80 & 0.569 \\
\hline 670 & Aerosol & 100 & $52 * 4$ & 4 & 27.0 & 9.00 & 0.583 \\
\hline $68 c$ & Anrosol & 100 & 52.4 & 5 & 25.0 & 11.50 & 0.768 \\
\hline 690 & Aerosol & 100 & 62.4 & 4 & 25.0 & 10.40 & 0.684 \\
\hline 700 & Aerosol & 100 & 52.4 & 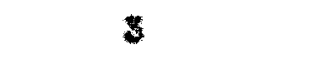 & 25.0 & 8.00 & 0.439 \\
\hline$n e$ & Aerosol & 100 & 52.4 & 2 & 25.0 & 5.60 & 0.359 \\
\hline 720 & Aerosol & 100 & 52,4 & 1 & 25.2 & 3.40 & 0.120 \\
\hline 730 & ferosol & 100 & 52,4 & $\$$ & 25.0 & 6.20 & 0.382 \\
\hline 740 & Lerosol & 100 & 52.4 & 2 & $2 \% 0$ & 5.60 & 0.331 \\
\hline 756 & Aerosol & 100 & $52 \cdot 4$ & 1 & 26.0 & 5.50 & 0.287 \\
\hline $78 C$ & Aarosol & 100 & 52.4 & 3 & 25.1 & 8.10 & 0.447 \\
\hline $77 \mathrm{C}$ & Aerosol & 100 & 52.4 & 2 & 24.5 & 5.50 & 0.532 \\
\hline
\end{tabular}




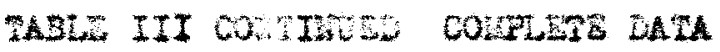

\begin{tabular}{|c|c|c|c|c|c|c|c|}
\hline $\begin{array}{l}\text { Bun } \\
\text { sitstabor }\end{array}$ & $\begin{array}{l}\text { wetting } \\
\text { hant }\end{array}$ & 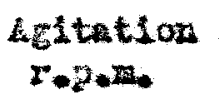 & 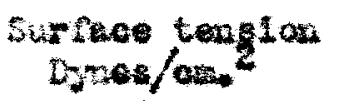 & $\begin{array}{c}\text { Afitation } \\
\text { tinutos }\end{array}$ & $\begin{array}{l}\text { Tezperacure } \\
\text { Degreos } C .\end{array}$ & 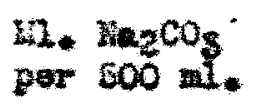 & $\begin{array}{l}\text { Lols } \mathrm{co}_{2} \times 10^{3} \\
\text { per nol }\end{array}$ \\
\hline 780 & harosol & 100 & 52.4 & 1 & 25.2 & 5.10 & 0.158 \\
\hline 790 & Arosol & 200 & 52.4 & 0 & 25.6 & 1.40 & 0.000 \\
\hline 800 & Aerosol & 100 & 52.4 & 0 & 25.0 & 0.00 & 0.000 \\
\hline 810 & harosol & 100 & $52 * 4$ & 0 & 24.6 & 1.00 & 0.000 \\
\hline 820 & Avrosol & 100 & 52.4 & 1 & 24.5 & $4.30 *$ & 0.245 \\
\hline 830 & Aerosol & 100 & 52.6 & 2 & $24 \cdot 3$ & 7.10 & 0.447 \\
\hline eAt & Aerosol & 100 & 52.6 & 3 & 25.0 & 9.50 & 0.620 \\
\hline 860 & 4erosol & 200 & 524 & 2 & 25.0 & 7.00 & 0.639 \\
\hline $86 \mathrm{C}$ & Arosol & 200 & $52 \cdot 4$ & 2 & 25.0 & 5.60 & 0,524 \\
\hline $67 \mathrm{C}$ & Aerosol & 100 & 52.4 & 8 & 24.6 & 7.10 & 0.447 \\
\hline $00 \mathrm{C}$ & Aerosol & 100 & 46.5 & 2 & 25.1 & 5.70 & 0.346 \\
\hline 890 & $10: 0801$ & 100 & 46.3 & 1 & $24=3$ & 3.00 & 0.194 \\
\hline 900 & comosol & 100 & 46.3 & 3 & $26 \cdot 6$ & 7.50 & 0.475 \\
\hline 910 & Aerosol & 100 & 46.3 & 1 & 25.2 & 5.50 & 0.187 \\
\hline
\end{tabular}

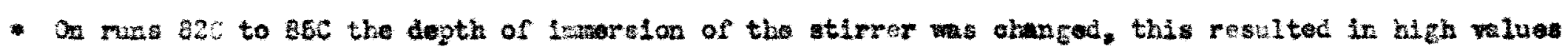




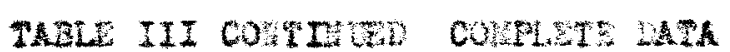

\begin{tabular}{|c|c|c|c|c|c|c|c|}
\hline Fur & $\begin{array}{l}\text { wettin } \\
\text { Lgent }\end{array}$ & $\begin{array}{l}\text { Aritation } \\
\text { r.p.z. }\end{array}$ & $\begin{array}{l}\text { Surfece tendon } \\
\text { Dynes/cal } 2\end{array}$ & $\begin{array}{c}\text { Actietion } \\
\text { vinutes }\end{array}$ & $\begin{array}{l}\text { Temperaturo } \\
\text { Decreas } c\end{array}$ & $\begin{array}{l}11 . \sin _{2} \mathrm{CO}_{3} \\
\text { per } 500=1 .\end{array}$ & $\begin{array}{l}\operatorname{lol} \mathrm{Co}_{2} \times 10^{3} \\
\text { per } \mathrm{xol}^{3} \text { ter }\end{array}$ \\
\hline $92 c$ & herosol & 100 & 66.3 & 2 & $2 E .0$ & 5.50 & 0.831 \\
\hline 930 & Aorosol & 100 & 4.5 & 8 & 25.2 & 0.80 & 0.425 \\
\hline $94 \mathrm{c}$ & krosol & 100 & 46.3 & 1 & 25.0 & 3.05 & 0.100 \\
\hline 550 & Jerosol & 100 & 45.3 & 2 & 26.0 & $\$ .10$ & 0.525 \\
\hline 96 & Acrosol & 100 & 46 & 3 & 25.5 & 7.00 & 0.489 \\
\hline $97 \%$ & Aerosol & 100 & 46.3 & 0 & 28.0 & 1.40 & 0.000 \\
\hline $9 e c$ & serosol & 100 & 46.5 & 0 & $2 E .1$ & 1.20 & 0.000 \\
\hline 920 & atonol & 100 & 46.3 & 0 & $2 E .2$ & 1.20 & 0.000 \\
\hline 1000 & herosol & 100 & 50.0 & 2 & $2 t .9$ & 5.10 & 0.303 \\
\hline 1010 & Aerosol & 100 & 50.0 & 1 & 25.2 & $\$ 30$ & 0.209 \\
\hline 1020 & Aerosol & 100 & 50.0 & 8 & $2 \varepsilon, 2$ & 6.40 & 0.396 \\
\hline 1020 & Aerozol & 100 & 50.0 & 3 & $2 E_{*} ?$ & 7.10 & 0.447 \\
\hline $104 \mathrm{C}$ & Aerosol & 100 & 50.0 & 2 & 25 & 5.50 & 0.217 \\
\hline 1050 & tarobol & 100 & 50.0 & 1 & 25.3 & 3.40 & 0.180 \\
\hline $100 \mathrm{C}$ & kerobol & 100 & $-m$ & 3 & 28.0 & 6.90 & 0.482 \\
\hline
\end{tabular}




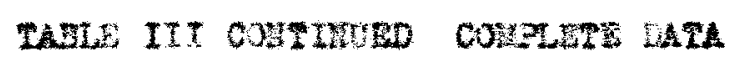

\begin{tabular}{|c|c|c|c|c|c|c|c|}
\hline $\begin{array}{l}\text { Iun } \\
\text { Nutaber }\end{array}$ & r atotis & $\begin{array}{l}\text { Agltation } \\
r \cdot p=20 .\end{array}$ & $\begin{array}{l}\text { Surfece ter } g^{10 x} \\
\text { Dymes/on. }\end{array}$ & $\begin{array}{l}\text { Agtation Iind } \\
\text { Unutes }\end{array}$ & $\begin{array}{l}\text { Texperature } \\
\text { recrees } \mathrm{C} .\end{array}$ & per ${ }^{20} \mathrm{ne}_{2} \mathrm{CO}_{3}$. & 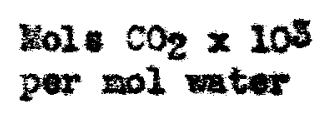 \\
\hline $107 \mathrm{C}$ & Aeroesol & 100 & - & 3 & 25.8 & 6.50 & 0.403 \\
\hline $100 \mathrm{C}$ & Aerosol & 100 & - & 2 & 25.7 & 4.70 & 0.278 \\
\hline 1000 & arosol & 100 & - & 1 & 20.5 & 3.30 & 0.178 \\
\hline 1100 & Aerosol & 100 & & 3 & 25,3 & 6.00 & 0.367 \\
\hline 1110 & Aerosol & 100 & 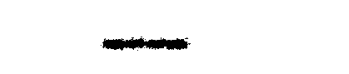 & 2 & 25.5 & 3.40 & 0.180 \\
\hline $112 \mathrm{C}$ & Aerosol & 100 & 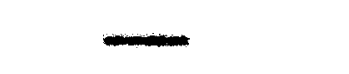 & 3 & 24.5 & 5.60 & 0.385 \\
\hline 1130 & Aerosol & 100 & - & 2 & 24.6 & 3.50 & 0.216 \\
\hline 1140 & Aorosol & 100 & - & 1 & 24.6 & 3.40 & 0.180 \\
\hline 1150 & Aerosol & $3 * 100$ & 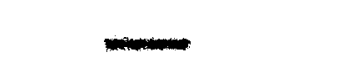 & 3 & 25.0 & 16.40 & \\
\hline 1160 & Aerosol & 100 & - & 2 & 25.0 & 15.20 & - \\
\hline 1170 & Aerosol & 100 & $-m$ & 0 & 25.0 & 12.20 & - \\
\hline 1180 & Santomerse & D 100 & $2 \sqrt{*} 3$ & 3 & 28.0 & B.80 & 0.533 \\
\hline 1190 & Suntoratro & 100 & 23.3 & 2 & 24.5 & 4.70 & 0.275 \\
\hline $1200 ?$ & $\operatorname{santane} 30$ & $=100$ & 23.3 & 1 & 25.0 & 2.90 & 0.144 \\
\hline
\end{tabular}

* Aerosol s contalned acld as atabilizer and therefore interfored in the cerbonato titration. 


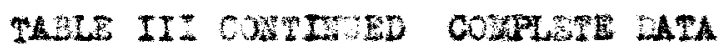

\begin{tabular}{|c|c|c|c|c|c|c|c|c|}
\hline Pin & $\begin{array}{l}\text { retilat } \\
\text { or Agent }\end{array}$ & & 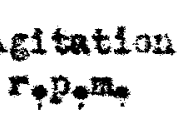 & $\begin{array}{l}\text { Surfece texision } \\
\text { Dymes/on. } 2\end{array}$ & $\begin{array}{c}\text { Agitation rs } \\
\text { zinutes }\end{array}$ & 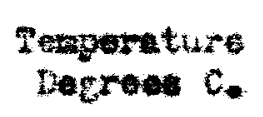 & $\begin{array}{l}\text { 11. } \\
\text { perat } 500 \mathrm{cog}\end{array}$ & $\begin{array}{l}\text { sol } \mathrm{co}_{2} \times 10^{3} \\
\text { par }\end{array}$ \\
\hline $121 \mathrm{C}$ & Suntomeres & $\mathbf{D}$ & 100 & 23,3 & 3 & 25.0 & 6.00 & 0.367 \\
\hline 1220 & Semtoserse & $D$ & 100 & 23.3 & $z$ & 25.0 & 4.65 & 0.270 \\
\hline $123 \mathrm{C}$ & Sentanerse & $D$ & 100 & 23.8 & 1 & 24.8 & 3.20 & 0.178 \\
\hline $124 \mathrm{C}$ & Suntaberse & $D$ & 100 & $23 \cdot 3$ & 3 & 25.0 & 6.10 & 0.375 \\
\hline 1250 & Suntoners: & $D$ & 100 & $2 a^{3}$ & 2 & 25.2 & 4.60 & 0.267 \\
\hline 1268 & Santomerse & $D$ & 100 & $23 \cdot 3$ & 1 & 25.0 & $3 . \infty$ & 0.151 \\
\hline 2270 & Santorerse & $D$ & 100 & $2 z_{3}=$ & 0 & 25.0 & 0.90 & 0.000 \\
\hline 1280 & sastowera & $D$ & 100 & 23.3 & 0 & 25.0 & 0.90 & 0.000 \\
\hline 1220 & Sertomerse & $\mathbf{D}$ & 100 & 22,0 & 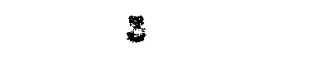 & 25.0 & 6.50 & 0.408 \\
\hline $1: 00$ & Sentoderse & $D$ & 100 & 22.0 & 2 & 24.6 & 4.50 & 0.281 \\
\hline 1310 & Sentouerea & $\mathrm{D}$ & 100 & 22.0 & 1 & 25.0 & 3.10 & 0.158 \\
\hline $132 \mathrm{C}$ & Sentoluerse & D & 100 & 22.0 & 3 & 25.0 & 6.50 & 0.408 \\
\hline $138 \mathrm{C}$ & Santoserte & $D$ & 100 & 22.0 & 2 & 24.6 & 6.40 & 0.255 \\
\hline $134 \mathrm{C}$ & Fentomers & 2 & 100 & 22.0 & 1 & 24.7 & 3.10 & 0.253 \\
\hline 1350 & Sentonerse & $D$ & 100 & 22.0 & * & 25.2 & 6.10 & 0.375 \\
\hline
\end{tabular}




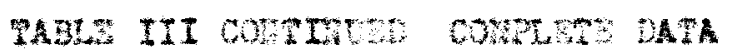

\begin{tabular}{|c|c|c|c|c|c|c|}
\hline 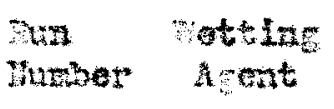 & 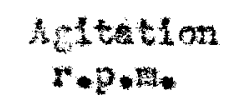 & 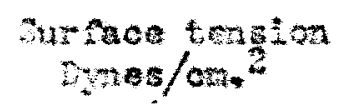 & $\begin{array}{l}\text { Aritation Tino } \\
\text { Minutes }\end{array}$ & $\begin{array}{c}\text { Tamaraturé } \\
\text { Dogres } 0 .\end{array}$ & $\begin{array}{l}\text { 11. } \operatorname{mat}_{203} \\
\text { per } 500 \text { n. }\end{array}$ & $\begin{array}{l}\text { lols } 00_{2} \times 10^{3} \\
\text { per wol tor }\end{array}$ \\
\hline 1s6C ontoterse & D 100 & 22.0 & 2 & $2 \epsilon .5$ & 4.75 & 0.277 \\
\hline 1370 Suntomerate & D 100 & 2.0 & 1 & 25.1 & 3.10 & 0.158 \\
\hline 15ec Santamerse & $D 100$ & 27.0 & 3 & $25 \cdot 2$ & 5.60 & 0.410 \\
\hline 1390 stnta: & D 100 & 27.0 & 2 & 25.0 & 5.10 & 0.303 \\
\hline 1400 sentogerse & 100 & 27.0 & 1 & 2500 & 2.30 & 0.122 \\
\hline 1410 sentomense & D 100 & 27.0 & 3 & 25.0 & 6.40 & 0.356 \\
\hline 142C Sentorarse & $D 100$ & 27.0 & 2 & 25.5 & 4.60 & 0.251 \\
\hline 163C Santowarso & D 100 & 27.0 & 1 & 25.6 & 3.00 & 0.151 \\
\hline 1440 Bntonenta & D 100 & 27.0 & $\mathbf{3}$ & 25.0 & 6.50 & 0.403 \\
\hline 1450 Suntanose & D 100 & 27.0 & 2 & 24.5 & $=$ & $=$ \\
\hline $146 \mathrm{C}$ santonerse & D 100 & 27.0 & 1 & 25.0 & 2.80 & 0.137 \\
\hline 1470 sembortate & $D 100$ & 39.0 & 2 & 25.0 & 3.00 & 0.203 \\
\hline 150 Sentorerat & (1) 100 & 39.0 & 1 & 26.0 & 2.00 & 0.144 \\
\hline $349 \mathrm{C}$ Santosarse & 100 & 39.0 & 2 & 24.5 & 4.70 & 0.279 \\
\hline 1500 Buntosiar & 100 & 38.0 & 1 & 25.0 & 2.30 & 0.144 \\
\hline $161 \mathrm{C}$ Sentoneras & D 100 & 39.0 & 2 & 25.0 & 2.90 & 0.144 \\
\hline
\end{tabular}




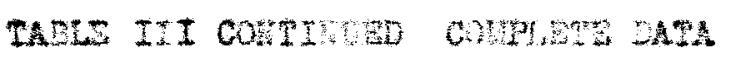

\begin{tabular}{|c|c|c|c|c|c|c|}
\hline 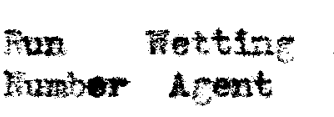 & 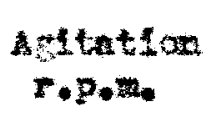 & $\begin{array}{l}\text { Drrace tenstor: } \\
\text { irnas/on }\end{array}$ & $\begin{array}{c}\text { A taton tino } \\
\text { Wutes }\end{array}$ & $\begin{array}{l}\text { sezperaturo } \\
\text { De }\end{array}$ & $\begin{array}{l}\text { a. } \operatorname{mec}_{3} \cos _{3} \\
\text { por }\end{array}$ & $\begin{array}{l}\text { yol. } \cos ^{2} \times 10^{\circ} \\
\text { por nol water }\end{array}$ \\
\hline $152 \mathrm{C}$ Suntomar & 80 100 & 45.0 & 2 & 25.0 & 4.70 & 0.274 \\
\hline 158c Sartoners & $D 100$ & 45.0 & 1 & 25.0 & 3.20 & 0.165 \\
\hline 1540 Santorerse & D 200 & 45.0 & 2 & 25.0 & 4.60 & 0.267 \\
\hline 1EEC santomere & D 100 & 48.0 & 1 & 25.0 & 5.30 & 0.175 \\
\hline 16sc Santoserse & 100 & 45.0 & 2 & 25.0 & $E \cdot \infty$ & 0.295 \\
\hline 1570 sentomers & 1100 & 45.0 & 1 & 25.0 & 2.25 & 0.162 \\
\hline $158 c \operatorname{santomers}$ & 100 & 4.0 & 2 & $2 \leq .0$ & $E=30$ & 0.000 \\
\hline 1590 Sancorerso & D 100 & 40.0 & 1 & $24 \cdot 2$ & 4.10 & 0.231 \\
\hline 1500 santonerso & 100 & 42.0 & 1 & 25.0 & 4.05 & 0.227 \\
\hline $161 C$ Santowerso & D 100 & 43.0 & 1 & 25.0 & 3.20 & 0.209 \\
\hline lozc Santorer & D 100 & 49.0 & 1 & 25.2 & 3.20 & 0.258 \\
\hline 1636 Sertoners & 0100 & $\$ 9.0$ & 2 & 25,0 & $5 . \pm 0$ & 0.017 \\
\hline 1640 santomerso & D 100 & 43.0 & 1 & 26.0 & 3.50 & 0.137 \\
\hline 1850 Santortore & 100 & 10.0 & 1 & $2 E .0$ & $4.0 \%$ & 0.227 \\
\hline 166C Sentomersa & D 100 & 49.0 & 1 & 25.0 & 3.00 & 0.204 \\
\hline
\end{tabular}




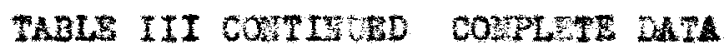

\begin{tabular}{|c|c|c|c|c|c|c|c|}
\hline $\begin{array}{l}\text { Nun } \\
\text { Tumbe }\end{array}$ & or Areting & $\begin{array}{l}\text { Agitation } \\
\text { ropesa }\end{array}$ & $\begin{array}{l}\text { Surface tension } \\
\text { Dyneo/ore. }\end{array}$ & $\begin{array}{c}\text { Agltation timo } \\
\text { timutes }\end{array}$ & $\begin{array}{l}\text { Ienperature } \\
\text { Degrees } C .\end{array}$ & 17. $\operatorname{xag}_{2} \operatorname{cog}^{\circ}$ & $\begin{array}{l}\text { Lol: } \mathrm{Co}_{2} \times 10^{3} \\
\text { per mol water }\end{array}$ \\
\hline $167 \mathrm{C}$ & Sattorarse D & 100 & 49.0 & 1 & 28.0 & 4.40 & 0.252 \\
\hline $168 \mathrm{C}$ & Sentomerse D & 100 & 43.0 & 1 & 25.0 & 3.15 & 0.162 \\
\hline 1500 & Sentonerse D & 100 & 40.0 & 1 & 25.0 & 3.46 & 0.184 \\
\hline $170 c$ & Sentogerse D & 100 & 49.0 & $\mathbf{I}$ & 25.0 & 3.50 & 0.287 \\
\hline 1710 & Satoxidae $D$ & 100 & 58.0 & 1 & 25.2 & 8.60 & 0.194 \\
\hline 1720 & sentoserse D & 100 & 60.0 & 1 & 26,0 & 3.70 & 0.201 \\
\hline $173 \mathrm{C}$ & Sentomerse D & 100 & 52.0 & $\mathbf{2}$ & 25.0 & 3.60 & 0.124 \\
\hline 1740 & Suntoverse D & 100 & 40.0 & 1 & 25.0 & $s_{3} 10$ & 0.158 \\
\hline 1750 & Seatodorse D & 100 & 40.0 & 1 & 25.0 & 3.20 & 0.286 \\
\hline $1760:$ & santorerse 0 & 100 & 40.0 & 1 & 25.0 & س & 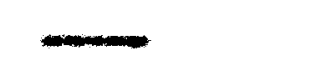 \\
\hline $177 \mathrm{C}$ & Sontouarae D & 100 & 40.0 & 1 & 25.0 & 8,25 & 0.169 \\
\hline 1780 & Santonerse $D$ & 200 & 40.0 & 1 & 25.0 & 3.70 & 0.201 \\
\hline 1790 & Sentomse D & 200 & 40.0 & 1 & 26.0 & 3.70 & 0.201 \\
\hline 1000 & Santosuerse $D$ & 200 & 10.0 & 1 & 25,0 & 2.75 & 0.205 \\
\hline $1010:$ & Santonerse D & 200 & $8 z_{*} 0$ & 1 & $24=8$ & 4.10 & 0.273 \\
\hline $1820:$ & sutonerse D & 200 & 52.0 & 1 & 25.0 & 3.70 & 0.201 \\
\hline
\end{tabular}




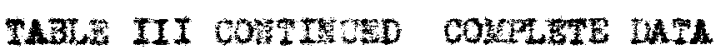

\begin{tabular}{|c|c|c|c|c|c|c|c|}
\hline Tun & ar metting & 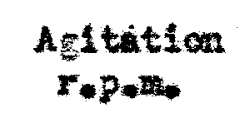 & $\begin{array}{l}\text { Surfuce tengion } \\
\text { Dynes/on. }\end{array}$ & 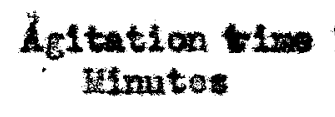 & $\begin{array}{l}\text { Temperature } \\
\text { Degrees } c .\end{array}$ & per. ${ }^{1400} \mathrm{Co}_{3}$ & $\begin{array}{l}\text { wols } \cot _{2} \times 10^{3} \\
\text { por wol } \text { weter }\end{array}$ \\
\hline $183 \mathrm{D}$ & Santoris: & D 200 & 52.0 & 1 & 25.0 & 8.60 & 0.104 \\
\hline 1040 & Santoserse & 0200 & 52.0 & 1 & 25.0 & 3.75 & 0.205 \\
\hline 1850 & Sentomar & 1200 & 61.0 & 1 & 25.0 & 4.20 & 0.237 \\
\hline 1860 & Santomerse & $D \quad 200$ & 61.0 & 1 & 25.0 & 4.20 & 0.287 \\
\hline 1870 & Estomareo & $0 \quad 200$ & 61.0 & 1 & 25.0 & 1.30 & 0.245 \\
\hline 1000 & Suntone & 1200 & 61.0 & 1 & 26.0 & 4.00 & 0.228 \\
\hline 1890 & Satowarta & $D 200$ & 82,0 & 1 & 28.0 & 3,00 & 0.216 \\
\hline 1000 & Sentomerse & D 200 & 61.0 & 1 & 25.0 & 4.00 & 0.228 \\
\hline 1910 & Santonatse & D 200 & 34.0 & $\mathbf{1}$ & 25.0 & 4.30 & 0.245 \\
\hline 1925 & Santonere & D 200 & 3.0 & 1 & 25.0 & 4.10 & 0.231 \\
\hline $195 \mathrm{D}$ & Santoserso & $D \quad 200$ & 54.0 & 1 & 25.0 & 3.90 & 0.216 \\
\hline $198 \mathrm{~L}$ & San torer: & D 200 & 36.0 & 1 & 25.0 & 3.96 & 0.220 \\
\hline 1960 & Sentonerse & D 200 & 34.0 & 1 & 25.0 & 3.90 & 0.216 \\
\hline 1900 & Sartomerso & 1200 & 31.0 & 1 & 27.0 & 4.70 & 0.273 \\
\hline 1070 & santowerse & D 200 & 31,0 & 1 & 25.0 & 4.40 & 0.252 \\
\hline 1980 & Suntomerse & $D 200$ & 31.0 & $\mathbf{1}$ & 25.0 & 4.10 & 0.231 \\
\hline
\end{tabular}




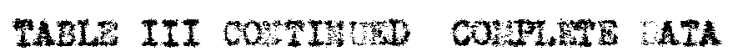

\begin{tabular}{|c|c|c|c|c|c|c|c|}
\hline Thes & $\begin{array}{c}\text { yotring } \\
\text { Agert }\end{array}$ & $\begin{array}{l}\text { Aritation } \\
\text { rapminan }\end{array}$ & $\begin{array}{l}\text { Surthoe tomator } \\
\text { Dynes/ones }\end{array}$ & $\begin{array}{l}\text { Agitation tiae } \\
\text { vinutes }\end{array}$ & $\begin{array}{l}\text { Dempoture } \\
\text { Dogreos C. }\end{array}$ & 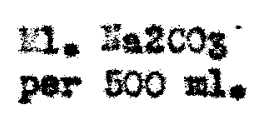 & $\begin{array}{l}\text { Dols } \mathrm{CO}_{2} \times 10^{5} \\
\text { per }\end{array}$ \\
\hline 1990 & Santomarse D & 200 & 31.0 & 1 & 25,0 & 4.00 & 0.256 \\
\hline 2000 & Sentomerse D & 200 & 51.0 & 1 & 25,0 & 4.50 & 0.259 \\
\hline 2010 & Eome & 200 & 70.0 & 1 & 25.0 & 3.90 & 0.216 \\
\hline 2020 & Wone & 200 & 70.0 & 1 & 26.0 & 4.20 & 0.231 \\
\hline $20 \% \mathrm{D}$ & Yone & 200 & 70.0 & 1 & 25.0 & 4.60 & 0.252 \\
\hline 2040 & wone & $\mathbf{2 0 0}$ & 70.0 & 1 & 25,0 & 4.40 & 0.252 \\
\hline 2056 & $\operatorname{Tan} \theta$ & 200 & 70.0 & 1 & 25.0 & 4,00 & 0.223 \\
\hline $206 \mathrm{C}$ & Hone & 100 & 70.0 & 1 & 25.0 & $3 . E 0$ & 0.187 \\
\hline $207 c$ & vone & 100 & 70.0 & 1 & 25.0 & 4.00 & 0.228 \\
\hline 208雚 & n-ntenol & 400 & 38.0 & 1 & 25.0 & 2.30 & 0.004 \\
\hline $209 \mathbb{P}$ & n-xutanol & $\$ 00$ & 30.0 & 1 & 25.0 & 9.60 & 0.626 \\
\hline 210 & -3utanol & 400 & 38.0 & 1 & 25.0 & 9.70 & 0.653 \\
\hline $211 \mathrm{E}$ & n-Butano1 & 400 & 38,0 & 1 & 25.0 & 3.80 & 0.041 \\
\hline $222 \mathrm{E}$ & $n$ - Sutanol & 400 & 40.0 & 1 & 25.0 & 9.00 & 0.582 \\
\hline 2258 & n-5utanol & 400 & 48.0 & 1 & 25.0 & 9.70 & 0.635 \\
\hline 2142 & $2-32 \tan 01$ & 400 & 48.0 & 1 & 25.0 & 9.20 & 0.597 \\
\hline
\end{tabular}




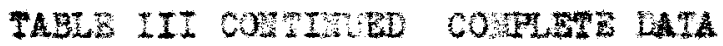

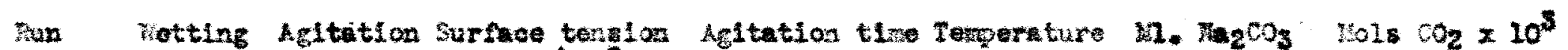

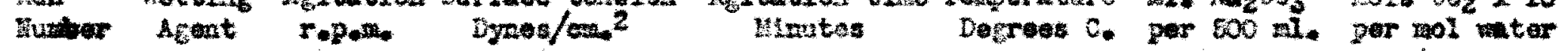

\begin{tabular}{|c|c|c|c|c|c|c|c|}
\hline 225 & $n-3 u \tan 01$ & 400 & 40.0 & 1 & 26.0 & 9.20 & 0.597 \\
\hline 226 & 2utanol & 400 & 48.0 & $I$ & 25.0 & 8.10 & $0.51 \%$ \\
\hline $217 \mathrm{~B}$ & $n-x u \tan 01$ & 400 & 52.0 & 1 & 25.0 & 3.00 & 0.585 \\
\hline 2108 & ambutanal & 100 & 52.0 & 1 & 25.0 & 8.70 & 0.562 \\
\hline $219 x$ & $n-5 a \tan 01$ & 400 & 52.0 & 1 & 25.0 & 8.66 & 0.567 \\
\hline $220 \mathrm{~s}$ & n-3utanol & 400 & 57.5 & 1 & 25.2 & 2.65 & 0.587 \\
\hline 2215 & $n-3 u \tan 01$ & 100 & 57.5 & 1 & 25,0 & 8.20 & 0.526 \\
\hline 2228 & $n-3 c \tan a 1$ & 100 & 57.5 & 1 & 26,0 & E.EO & 0.547 \\
\hline $228 \mathrm{E}$ & $n-3 u t a n o l$ & 400 & 57.6 & 1 & 25.0 & 8.30 & 0.533 \\
\hline $225 \mathrm{E}$ & $n-5 u t a n 01$ & 400 & 57.5 & 1 & 26.0 & 8. 30 & 2.585 \\
\hline 2868 & $n-3 u \tan a 1$ & 400 & 66.0 & 1 & 25.0 & 8.30 & 0.535 \\
\hline $226 E$ & $n-\operatorname{sutan} 01$ & 400 & 65.0 & 1 & 25.0 & 8.00 & 0.612 \\
\hline $227 \mathrm{E}$ & $n-3 \operatorname{stanol}$ & 400 & 68.0 & 1 & 25.0 & 8.10 & 0.517 \\
\hline 228 & D-Extanol & 100 & 65.0 & 1 & 25.0 & 8.00 & 0.812 \\
\hline 220 & $n-B u \tan 01$ & 400 & 70.0 & 1 & $25 \cdot 0$ & 6.30 & 0.389 \\
\hline 2302 & $n-R a t a n o l$ & 400 & 70.0 & 1 & 25.0 & 6.40 & 0.320 \\
\hline 2810 & F-3utanol & 200 & 43.0 & $\mathbf{2}$ & 25.0 & 7.00 & 0.439 \\
\hline
\end{tabular}




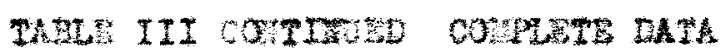

\begin{tabular}{|c|c|c|c|c|c|c|c|}
\hline Tun & $\begin{array}{c}\text { Fetting } \\
\text { Agent }\end{array}$ & $\begin{array}{l}\text { AEItatiom } \\
\text { Fon }\end{array}$ & $\begin{array}{l}\text { Aurace tenglon } \\
\text { Syes/on. }\end{array}$ & $\begin{array}{c}\text { Agltates on the } \\
\text { sinuts: }\end{array}$ & $\begin{array}{c}\text { Tamporaturs } \\
\text { Defrees } C_{.}\end{array}$ & $\begin{array}{l}\text { 32. } \mathrm{N}_{2} \mathrm{cog} \\
\text { por } 000 \mathrm{ml}\end{array}$ & $\begin{array}{l}\text { vol: } \mathrm{CO}_{2} \times 10^{3} \\
\text { per tol water }\end{array}$ \\
\hline 2320 & $n-2 x \tan$ ol & 200 & 4.0 & 1 & 25.0 & 6.60 & 0.375 \\
\hline $235 \mathrm{~s}$ & $n-D u \tan 01$ & 200 & 43.0 & 1 & 25.0 & 2.60 & 0.403 \\
\hline 2340 & I-3extal & 200 & 43.0 & 1 & 25.0 & .40 & 0.326 \\
\hline 2350 & n-Iutanol & 200 & 47.0 & 1 & 25.0 & 6.40 & 0.396 \\
\hline 2360 & a-dutano1 & 200 & $\$ 4.0$ & 1 & 25.0 & 600 & 0.425 \\
\hline 2370 & n-3xtenol & 200 & 5.0 & 1 & 25.0 & $* . \infty 0$ & 0.567 \\
\hline 2380 & $n$-ntenol & 200 & 3.0 & 1 & 25.0 & $c .10$ & 0.375 \\
\hline 2305 & m-3utanol & 200 & 5.0 & 1 & $2 s .0$ & 5.35 & 0.304 \\
\hline 2400 & a-ntenol & 200 & we. 0 & 1 & 25.0 & 6.20 & 0.382 \\
\hline 2410 & $n-7 e \tan 01$ & 200 & 58.0 & 1 & 25.0 & $0 . \infty$ & 0.367 \\
\hline 2420 & $n-3 \cos ^{2}$ and & 200 & 58.0 & 1 & 25.0 & $6 . \infty$ & 0.367 \\
\hline $2 x 30$ & $x-\tan \tan$ & 200 & 58.0 & 2 & 26.2 & 5.50 & 0.339 \\
\hline 240 & n-Atano1 & 200 & 58.0 & 1 & 26.2 & 6.60 & 0.359 \\
\hline 245 & $n-3+t a 01$ & 200 & 52.0 & 1 & 26. & 5.60 & 0.353 \\
\hline 2460 & n-3uterol & 200 & 58.0 & 1 & 26.2 & 5.90 & 0.361 \\
\hline $24 \% \mathrm{D}$ & n-Pratenol & 200 & 01.0 & 1 & 26.2 & 6.60 & 0.539 \\
\hline
\end{tabular}




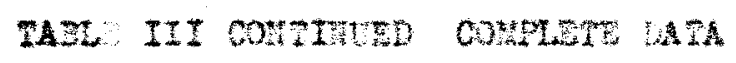

\begin{tabular}{|c|c|c|c|c|c|c|c|}
\hline $\begin{array}{l}\text { Fun } \\
\text { Futiver }\end{array}$ & setst & $\begin{array}{l}\text { Antetion } \\
\text { rep+am }\end{array}$ & $\begin{array}{c}\text { Surraco tenason } \\
\text { Dyes/ca.? }\end{array}$ & $\begin{array}{c}\text { Adtation the } \\
\text { vinutes }\end{array}$ & 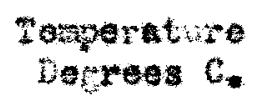 & 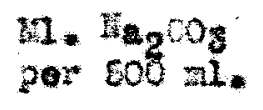 & $\begin{array}{l}\text { ol } \mathrm{co}_{2} \times 10^{3} \\
\text { por wol watar }\end{array}$ \\
\hline 2480 & $n-3 x \tan 01$ & 200 & 62.0 & 1 & 20.2 & 5.70 & 0.348 \\
\hline 243 & $n$-Wutanol & 200 & 0.0 & 1 & $26 \cdot 2$ & 5.70 & 0.348 \\
\hline 2500 & n-Butanol & 200 & 61.0 & 1 & 20,2 & 5.70 & 0.346 \\
\hline 2510 & $n$-lxtenol & 200 & 65.0 & 1 & 26.0 & 5.70 & 0.346 \\
\hline 2520 & $n-3 x \tan 01$ & 200 & 65.0 & 1 & 26.2 & 5.50 & 0.333 \\
\hline 2530 & $2-3 x \tan 01$ & 200 & 65.0 & 1 & $23 \cdot 2$ & 5.26 & 0.345 \\
\hline 2540 & n- & 200 & 05.0 & 2 & $26 \cdot 2$ & 5.70 & 0.346 \\
\hline 250 & $n$-3utanol & 10 & 65.0 & 1 & 20.2 & 5.85 & 0.357 \\
\hline $256 C$ & D-Ditanol & 100 & 6,0 & 2 & 26,2 & 5.60 & 0.331 \\
\hline $257 c$ & n- Butanol & 100 & 85.0 & 1 & 26.2 & 5.75 & 0.349 \\
\hline 260 & $n-B u t e n o l$ & 100 & 65.0 & 1 & 20.2 & 5.65 & 0.343 \\
\hline 2500 & z-Butanol & 100 & 65.0 & 1 & 26.2 & F. 30 & 0.862 \\
\hline 2000 & n- Intanol & 100 & 65.0 & 1 & 20.2 & 5.70 & 0.346 \\
\hline 2616 & n-3utarol & 100 & 80.0 & 1 & $24 \cdot 2$ & 8.80 & 0.583 \\
\hline 2620 & $n-30 t$ tenol & 100 & 29.0 & 1 & $2 * 2$ & 5.55 & 0.335 \\
\hline $263 c$ & 栔-3utenol & 200 & 20.0 & 1 & $24 \cdot 2$ & 8.50 & 0.381 \\
\hline
\end{tabular}




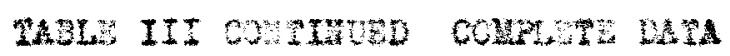

\begin{tabular}{|c|c|c|c|c|c|c|c|}
\hline Titun & $\begin{array}{l}\text { Tetting } \\
\text { A } \\
\text { Astant }\end{array}$ & $\begin{array}{l}\text { Aglation } \\
\text { F.p, st }\end{array}$ & $\begin{array}{l}\text { Surfece torston } \\
\text { Dyoes/on. }\end{array}$ & 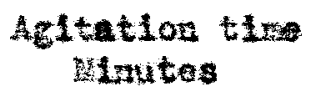 & $\begin{array}{c}\text { Texzerature } \\
\text { Degread } \mathrm{C} .\end{array}$ & 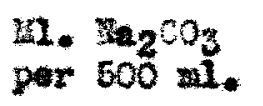 & $\begin{array}{l}\text { Nols } \mathrm{CO}_{2} \times 10^{8} \\
\text { per wol ater }\end{array}$ \\
\hline 2640 & - n-Dutanol & 100 & 23.0 & 1 & 24.2 & 8.10 & 0.375 \\
\hline 2650 & I-jutanol & 100 & 29.0 & 1 & 24,2 & 5.76 & 0.349 \\
\hline 2660 & E-Mutanol & 100 & 46.0 & 1 & 26.3 & 7.50 & 0.475 \\
\hline 2670 & $n-3 u t a n o 1$ & 100 & 56.0 & 1 & 24.3 & 6.60 & 0.120 \\
\hline 2080 & n-3utanol & 100 & 46.0 & 1 & 24.4 & 6.60 & 0.424 \\
\hline 2690 & n-Putanol & 100 & 40.0 & 1 & $2 * 4$ & 9.50 & 0.424 \\
\hline 2700 & 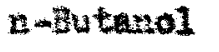 & 100 & 19.0 & 1 & 26.0 & 7.20 & 0.453 \\
\hline 2710 & $2-3 n+n a d$ & 100 & 49.0 & 1 & 25.1 & 7.00 & 0.438 \\
\hline $272 \mathrm{C}$ & a-1 & 100 & 49.0 & 1 & 25.1 & 7.15 & 0.460 \\
\hline $273 \mathrm{C}$ & a-vatanol & 200 & 01.0 & 1 & 25.3 & 5.40 & 0.393 \\
\hline 2780 & $2-30$ and & 100 & 61.0 & 1 & 25.3 & 5.70 & 0.546 \\
\hline 2750 & $n-52 \cos 01$ & 100 & 62.0 & 1 & 25.3 & 6.20 & 0.381 \\
\hline 2700 & n- & 100 & 61.0 & 1 & 25.3 & 6.30 & 0.389 \\
\hline $277 \mathrm{C}$ & $2-3 \tan \alpha 1$ & 100 & 61.0 & 1 & 28.2 & 6.10 & 0.290 \\
\hline $278 \mathrm{c}$ & $2-\mathrm{dutan} 01$ & 100 & 54.0 & 1 & 25.0 & 7.00 & 0.458 \\
\hline 2790 & n-Butanal & 100 & 点, 0 & 1 & 25.3 & 6.80 & 0.625 \\
\hline
\end{tabular}




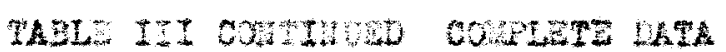

\begin{tabular}{|c|c|c|c|c|c|c|c|}
\hline hum & 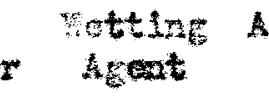 & $\begin{array}{l}\text { Aettation } \\
\text { r.D. }\end{array}$ & 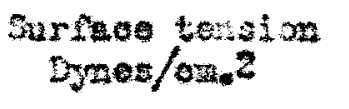 & 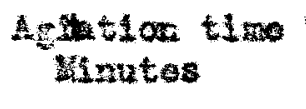 & $\begin{array}{l}\text { Faperature } \\
\text { Degroes }\end{array}$ & $\begin{array}{l}\text { 11. } \mathrm{F}_{2} \mathrm{CO} \\
\text { pex } 500 \mathrm{ml} \text {. }\end{array}$ & $\begin{array}{l}\text { vols } 60_{2} \times 10^{\circ} \\
\text { per wol wator }\end{array}$ \\
\hline 2000 & $2-3 \operatorname{tanol}$ & 100 & 54.0 & 1 & 25.0 & $E_{.} 80$ & 0.225 \\
\hline 2810 & $n-30 t a 201$ & 100 & $B E .0$ & 1 & $2 z_{.0}$ & 6.00 & 0.425 \\
\hline 2820 & x-3utanol & 100 & 70.0 & 2 & 25.0 & 4.40 & 0.252 \\
\hline 283 & $2-3 \tan 01$ & 100 & 70.0 & 1 & 25.0 & 4.70 & 0.274 \\
\hline 2640 & $n-B u+1$ & 100 & 70.0 & 1 & 25.0 & 4.70 & 0.274 \\
\hline $285 C$ & $x-3$ tanol & 100 & 70.0 & 1 & 25.0 & 4.70 & 0.274 \\
\hline 2660 & $n-3$ tasol & 200 & 70.0 & 2 & 25.0 & 6.0 & 0.367 \\
\hline 287 & $n$-butanol & 200 & 70.0 & 1 & 25.0 & 6.15 & 0.388 \\
\hline 2065 & $n-B=\tan 01$ & 200 & 70,0 & 1 & 25.0 & 6.70 & 0.418 \\
\hline 2690 & 1so-pentanol & 200 & 30.0 & 1 & 25.0 & 6.so & 0.250 \\
\hline 20051 & 18c-pertartol & 200 & $\$ 9.0$ & 1 & 25.0 & 7.20 & 0.453 \\
\hline $2915+$ & $200-2 \operatorname{asc} 2 \sin 01$ & 200 & 89.0 & 1 & 25.0 & 7.30 & 0.432 \\
\hline $2920^{3}$ & 1so-pentantal & 200 & 39.0 & 1 & 25.0 & 7.00 & 0.407 \\
\hline 2030 & aco-petanal & 200 & 39.0 & 2 & 25.0 & 7.00 & 0.457 \\
\hline
\end{tabular}


VIRA

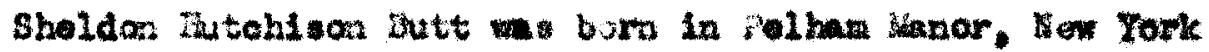
on Auguet 22, 1919. In 1927, he koved to Louldrilio, Kentuoly. We

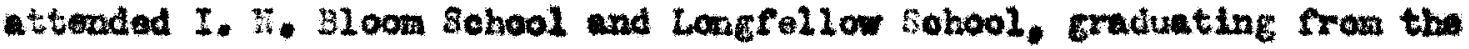

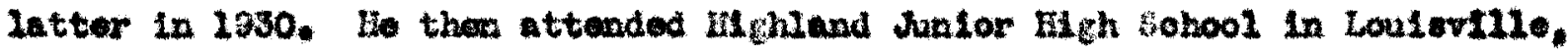
graduatiog in 19s\$. The then entered the Louloville kale Figh Sahool. fross whioh be graduated with donorable wontion in 1936. While in High sohool ho was active in dobating. belng prosldent of the Debato Club and ouptain of the Debate fean. In the fall of 1956, he wotered the speod selentifle school of the Univeretty of Loulurille. While

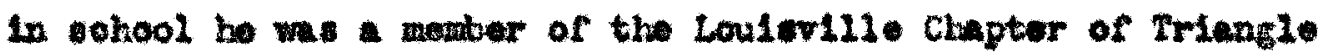

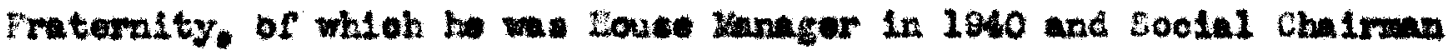

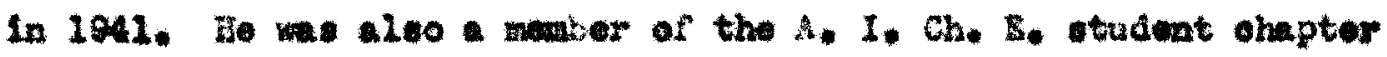

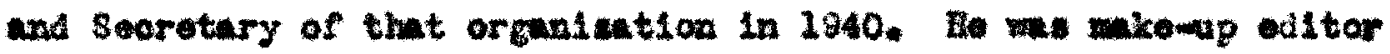
of the Viniverelty of Louleville Anmul In 2940 and Chairam of the

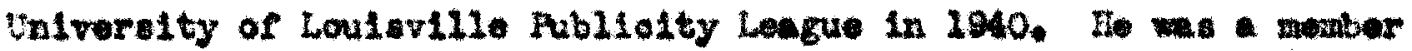
of Thota Cht Delth, honorary chenioal fraternity. and wos the Chondenl

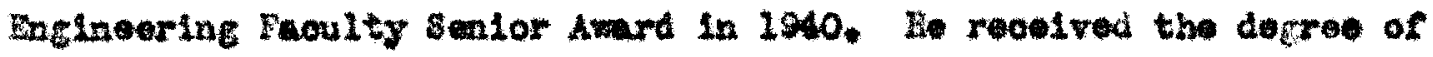

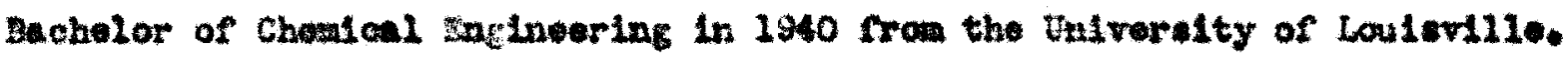

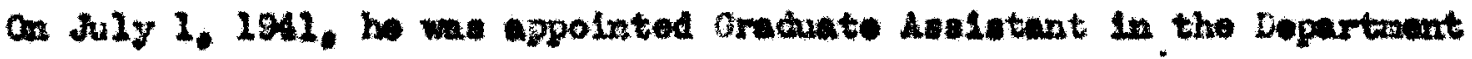
of Cherat on Inelnoerlng of the Iniversity of Loulurd12. 